öz

Çocukların açık kamusal mekân tasarımına katılımı sürecinde ele alınacak model ve izlenecek yöntemler, etkin bir tasarım süreci ve çocuklara yaşanabilir mekânlar yaratmak için önemlidir. Çocuk dostu açık kamusal mekânlar olușturabilmenin en önemli aracı çocuk katılımıdır, ancak sonucun niteliği bu süreçte seçilen model ve yöntemin ne kadar etkili olduğu ile doğrudan ilişkilidir. Katılım yöntemlerinin ne kadar etkili olduğunun anlaşılması, bundan sonraki çalışmalarda kullanılabilecek bir bilgi oluşturabilir. Bu nedenle, bu çalışmada açık kamusal mekân tasarım süreçlerinde uygulanan çocuk katılım yöntemlerinin tasarım/uygulama sürecinde etkinlik düzeylerini

değerlendirmeye yönelik bir çerçeve ortaya konması amaçlanmıştır. Bunun için öncelikle literatürde tanımlanan katılım yöntemleri incelenmiş, biri Türkiye'den olmak üzere dünya üzerinde uygulanmıș altı örnek proje seçilerek kullanılan yöntemler üzerinden değerlendirilmiştir.

Örnek projeler üzerinden yapılan bu değerlendirmede katılımı sağlamaya yönelik birden fazla yöntemin kullanıldı $\breve{g}_{1}$, katılımc profiline (kültür, yaş, engel grubu, yetenek $v b$.) ve projenin amacına göre farkl yöntemlerin tercih edildiği, farklı katılım yöntemlerinin kullanılması farklı düzeylerde katılımı sağlarken, aynı yöntemin uygulamalardaki alternatif kullanımlarının katılım düzeyini ve projenin katılım sürecinin etkinliğini değiştirebildiği görülmüștür.

Açık kamusal mekân tasarımında uygulanan çocuk katılım süreçlerinde kullanılan yöntemlerin etkinliğinin değerlendirmesinin, gelecekte daha etkili katılım süreçlerinin planlanmasında kolaylık sağlayacağı ve yapılacak çocuk odaklı katılımcı açık kamusal mekân tasarımında seçilecek katılım yöntemleri için yol gösterici olacağ düşünülmektedir.

Abstract

Creating child-friendly open public spaces can be achieved through children participation and the relative success is directly related to the degree of the efficiency of the model and method conducted in a participatory process. Therefore, the aim of this study is to establish a framework for the evaluation of the efficiency level of children participation methods applied in open public space design and implementation processes. For achieving this goal, first the methods and models of children participation are scrutinized through the related literature and then these methods are evaluated on the selected six examples throughout the World including one from Turkey.

In each of the sample projects, it is identified that more than one method is used to ensure participation, and different methods are preferred according to the participant profile (culture, age, disability group, ability, etc.). It is concluded that the purpose of the project is decisive on the methods used. Besides, the use of different participation methods ensures participation at different

\title{
Açılk Kamusal Mekân Tasarımında Çocuk Katılım Yöntemlerinin Etkinlik Düzeyi Değerlendirmesi
}

Gülzade Şentürk Şehir Plancısı, Kentsel Tasarım Uzmanı, Yıldırım Belediyesi, Bursa

(D) Ebru Firidin Özgür Mimar Sinan Güzel Sanatlar Üniversitesi Mimarlık Fakültesi, Şehir ve Bölge Planlama Bölümü Başvuru tarihi/Received: 21.08.2020, Kabul tarihi/Final Acceptance: 19.10.2020

\section{Giriş}

Çocuklar toplumsal anlamda ötekileştirildikleri ve toplumun bir bireyi olarak ele alınmadıkları gibi yetişkinlerin belirlediği sınırlar içinde pasif konumda bulunmaktadırlar. Yetişkinler ya da profesyoneller tarafından belirlenen birtakım kriterler doğrultusunda tasarlanan açık kamusal mekânlar, çocuğun ihtiyaçlarına, beklenti ve isteklerine her zaman cevap verememektedir. Bugün, katılım konusundaki çalışmalar giderek gelişmesine rağmen, çocuk katılımı, çocukları ilgilendiren bazı projelerde sadece kısmi fikirlerinin alınması şeklinde algılanmakta ve sembolik olarak uygulanmaktadır. Oysa çocuk katılımı konusu, çocuğun kendi yaşamına ve yaşamını etkileyen her türlü alana, mekân üretim süreci de dâhil olmak üzere genişletilmelidir. Tüm bu nedenler, açık kamusal mekân tasarımında çocukların katılımını gerekli kılmaktadır.

Çocukların planlama ve tasarım sürecine katılımlarına ilişkin yaşanan ilkesel ve uygulamadaki gelişmeler, çocuklar için farklı katılım düzeylerinin ve yöntemlerinin de gelişmesini sağlamıştır. Çocukların katılımında kullanılacak katılım düzey ve yöntemleri ile birlikte, çocuğun ve yetişkinlerin/profesyonellerin katılımda sahip oldukları rollerle beraber katılım sürecinin tasarımı da önem kazanmaktadır. Bu nedenle çocukların açık kamusal mekân tasarımına katılımı sürecinde ele alınacak model ve izlenecek yöntemler, etkin bir tasarım süreci ve çocuklara yaşanabilir mekânlar yaratmak için önemlidir. Ancak karmaşık bir yapı olan çocuk katılımı sürecinde kullanılan yöntemlerin ne kadar etkili olduğu katılım süreci planlanırken genelde göz ardı edilmektedir. Oysaki çocuk dostu açık kamusal mekânlar oluşturabilmek çocuk katılımıyla sağlanabileceği gibi, bu süreçte seçilen model ve yöntemin ne kadar etkili olduğu ile doğrudan ilişkilidir. Bu nedenle açık kamusal mekân tasarımında çocuk katılım yöntemlerinin etkinlik düzeyi değerlendirmesinin, gelecekte yapılacak çocuk odaklı katılımcı açık kamusal mekân tasarımında seçilecek katılım yöntemleri için yol gösterici olacağı düşünülmektedir.

Bu çalışma ile açık kamusal mekân tasarım süreçlerinde uygulanan çocuk katılım yöntemlerinin tasarım/uygulama sürecinde etkinlik düzeylerini değerlendirmeye yönelik bir çerçevenin ortaya konması amaçlanmaktadır. Çalışma kapsamında, planlama ve tasarım alanında tanımlanan farklı çocuk katılım modelleri ve yöntemlerinin neler olduğu; açık kamusal mekân tasarımına çocukların katılımında kullanılan yöntemlerin neler olduğu ve nasıl uygulandığı; açık kamusal mekân tasarımında çocuk katılım yöntemlerinin etkinlik düzeylerini değer- 
lendirmeye yönelik kriterlerin neler olduğu ve bu kriterlerin nasıl uygulandığı araștırmanın alt sorularını oluşturmaktadır.

Bu kapsamda çalışma iki ana bölümden oluşmaktadır. İlk bölüm olan Çocukların Açık Kamusal Mekân Tasarımına Katılımı bölümünde; çocuk katılım kavramı ile gelişim süreci, planlama ve tasarım alanında tanımlanan farklı çocuk katılım modellerinin ve yöntemlerinin neler olduğu ve çocuk katılım yöntemlerinin etkinlik düzeylerini değerlendirmeye yönelik kriterlerin neler olduğu irdelenmektedir. Literatüre dayalı olarak ele alınan bu bölümde, ikinci ana bölüm için referans olacak çocuk katılım yöntemlerinin ve etkinlik değerlendirme kriterlerinin ortaya koyulabilmesi hedeflenmektedir. İkinci ana bölüm olan Uygulama Örnekleri Üzerinden Çocuk Katılım Yöntemlerinin Etkinlik Düzeyi Değerlendirmesi bölümü ise; çocukların açık kamusal mekân tasarımına katılımlarının sağlandığı uygulama örneklerine odaklanmaktadır. $\mathrm{Bu}$ bölümde uygulama örneklerinde kullanılan farklı çocuk katılım yöntemleri ile katılımc1 süreçlerin ortaya koyulması ve ilk bölümde tanımlanan yöntemler ve belirlenen kriterler referans alınarak, farklı katılım yöntemlerinin planlanması ve uygulanması süreçlerini içeren uygulama örnekleri üze- rinden etkinlik düzeyinin değerlendirilmesine yönelik bir çerçevenin sunulabilmesi amaçlanmaktadır.

Uygulama örneklerinin incelenmesi, yapılan literatür taraması ve değerlendirmesi ile bu çalışmada çocuk katılımının sağlandığg 1 açık kamusal mekân tasarımı süreçlerinde kullanılan yöntemlerin etkinliğini değerlendirmeye yönelik 10 kriterden oluşan bir kriter dizini belirlenmiştir. Bunlar karara etki, tasarıma etki, katılım aşaması, kaynaklara erişim, şeffaflık, gönüllülük, çocuk dostu, kapsayıcılık, eğitim ile desteklenme ve hesap verebilirlik kriterleridir. Uygulamada kullanılan çocuk katılım yöntemlerini irdelemek için çocukların katılımlarının sağlandığı ve biri Türkiye'den olmak üzere, dünyanın farklı ülkelerinden altı uygulama örneği incelenmiştir. Projelerin incelemelerinin ardından, projelerde kullanılmış ve literatürde tanımlanmış olan 11 farklı katılım yöntemi belirlenmiştir. Belirlenen çocuk katılım yöntemlerinin etkinlik değerlendirme kriterlerini sağlayıp sağlamadığının derecelendirildiği matrisler ve grafikler oluşturularak etkinlik düzeyi değerlendirmesi yapılmıştır. Matrisler ve grafikler, katılım düzeyini görselleştirerek bir değerlendirme yapma olanağını sunmaktadır.

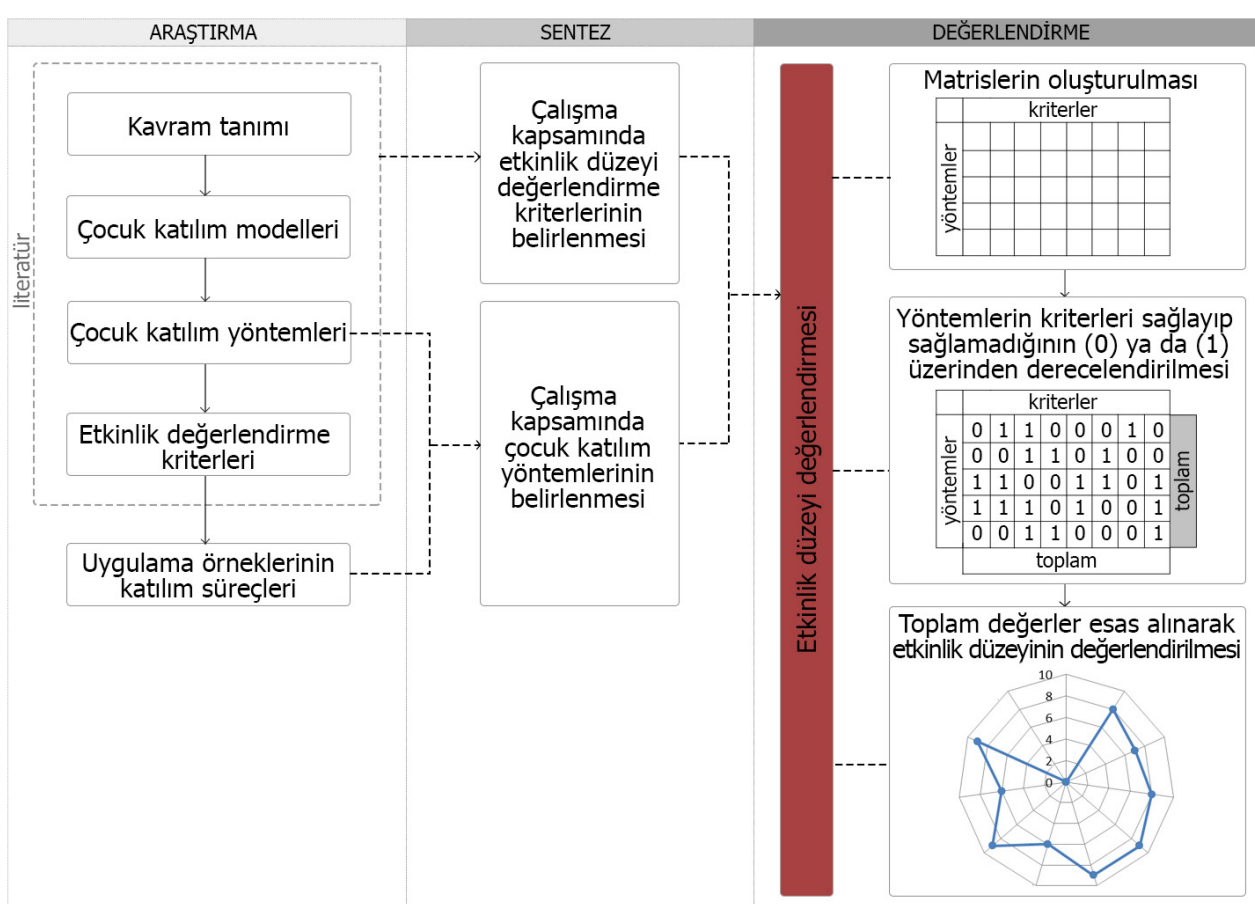

Şekil: I

levels, while using the same method in diverse projects could led to variances in the effectiveness of the participation.

It is believed that the evaluation of the effectiveness of the methods used in the children participation processes in the design of the open public space will facilitate the planning of more effective participation processes in the future and will guide the participation methods to be chosen in the child-oriented public space design.

Anahtar Kelimeler: Çocuk, katılım, açık kamusal mekân.

Keywords: Child, participation, open public space. 


\section{Çocukların Açık Kamusal Mekân Tasarımına Katılımı}

Çocuk Katılımı Tanımı ve Gelişim Süreci

Driskell'e (2002) göre katılım; insanların kendilerini ilgilendiren konularm planlanma ve karar verme sürecinde aktif olarak rol oynamasıdır. Bu süreç genel olarak; sorunun tanımlanması, konuyla ilgili verilerin toplanması ve analiz edilmesi, değişik yaş grubu ve düşüncelerin planlama ve karar verme sürecine katılımlarının sağlanması ve bu yolla alternatif kararların geliştirilmesi, en iyi karar için oybirliğine gidilmesi ve kararın uygulamaya konulması gibi aşamaları içermektedir. Katılım; yaş, cinsiyet, rrk ve etnik köken dikkate alınmaksızın toplumun her kesimini içine alan bir süreç olmalıdır.

Çocuk katılımı tanımı, ilk kez 1989'da BM Genel Kurulunca onaylanan Çocuk Haklarına Dair Sözleşme ile gündeme gelmiştir. Çocuk Haklarına Dair Sözleşme günümüzde de hala geçerliliğini koruyan en önemli gelişme olarak değerlendirilmektedir. Bu tarihten sonra yapılan çalışmaların çoğu bu sözleşmeyi kaynak alarak, sözleşmenin hayata geçirilmesi için yapılmış çalışmalar olmuştur. Çocuk Hakları Sözleşmesi'nin ve bunun gibi girişimlerin katılım maddelerinin, birçok coğrafyada hala uygulanabilir olamamasının en önemli nedeni ise katılım maddelerinin Batılı bir eğilim göstermesi, yaşanılan coğrafyaya göre değişkenlik gösteren kimlik gelişimi ve kültürü göz ardı etmesidir. Bu süreçte çocuk katılımına ilişkin birçok yasa, mevzuat yayınlanmış ve konferanslar gerçekleştirilmişse de; ülkemizde çocuk katılımına dair gelişmeler daha çok uluslararası gelişmeleri benimsemekle olmuş, bu gelişmelerin çoğu örgütlenme biçiminin etkin bir biçimde olmayışı, görev ve sorumlulukların açıkça tanımlanmaması, uygulamada nitelikli uzmanların yer almayışı, mali olanakların yetersizliği, istatistikî bilgilerin yetersizliği, kurumlar arası koordinasyon eksikliği vb. nedenlerle uygulamada yetersiz kalmışlardir.

Çocukların planlama ve kentsel tasarım süreçlerine katılımına ilişkin ilk uygulamalar ise 1960'lı yıllarda başlamıştır. Bu tarihten itibaren yaklaşık otuz yıllık bir süreçte çeşitli çalışmalar gerçekleştirilmiştir (Francis ve Lorenzo, 2002).

Uygulamada yaşanan aksaklıklar nedeniyle, farklı kültürlerdeki, farklı yaş ve cinsiyetteki çocukların katılımlarının etkin bir şekilde sağlanabilmesi için, farklı katılım modelleri ve yöntemleri tanımlanmıştır.

\section{Çocuk Katılım Modelleri}

Katılımı anlamak için düşünce ve metodolojilerin modellerini ele alan bir dizin oluşturulmuştur. Bu dizin oluşturulurken literatür araştırmasıyla 1969 yılından günümüze kadar öne sürülmüş 54 katılım modeli incelenmiş olup (Participation Models, 2012; Bang The Table, 2017); bu kat1lım modelleri arasında daha çok çocuk katılımına ilişkin modeller üzerinde ayrıntılı inceleme yapılmıştır. 1969 yılından günümüze kadar literatürde tanımlanan çocuk katılım modelleri dizini, katılımc tipleri ve katılım düzeylerine göre Tablo 1'de yer almaktadir.

Yapılan literatür taramasında çocuk katılımının uluslararası ve ulusal düzeyde yeni gelişim gösteren bir kavram olmas1 nedeniyle kavramsal anlamda yeterli verilere sahip olmadığı görülmüştür. Ancak Çocuk Haklarına Dair Birleşmiş Milletler Sözleşmesi'nin imzalanmasından bu yana, sözleşmenin 12. maddesi doğrultusunda çocuk katılımının geliştirilmesi için birçok kurum, kuruluş ve sivil toplum kuruluşları, çocukların katılımını giderek artan bir şekilde çalışmalarının odağı haline getirmişlerdir. Bu aynı zamanda kavramın ve düzeylerin aydınlatılması (Hart, 1992), iyi uygulama süreçlerinin belgelenmesi (Shier, 2001; 2010; 2014), uygulama rehberleri (Treseder, 1997; Save the Children, 2005) ve çocukların katılımı konusunda bir dizi yayının artmasına yol açmıştır.

$\mathrm{Bu}$ literatürün çoğunda en çok bahsedilen ve etkili olan model Hart'ın katılım merdiveni olmuştur. Bu model ilk olarak 1992 tarihli Hart'ın "Çocuk Katılımı: Sembolikten Yurttaşlığa" yapıtında görülmüş olup, sonrasinda defalarca yenilenmiştir (Hart, 1995, 1997). Hart'in bu modeli Arnstein'1n 1969 tarihli 'Vatandaş Katılımı Merdiveninin 8 Basamağı'nın bir uyarlamasıdır. 


\begin{tabular}{|c|c|c|}
\hline Referans/ Katılım Modeli & Katılımeı Tipi & Katılım Düzeyleri \\
\hline Arnstein (1969) & Tümü & $\begin{array}{l}\text { Merdiven modeli- } 8 \text { düzey: } \\
\text { 1) Manipülasyon, 2) Terapi, 3) Bilgilendirme, 4) Danışma, } \\
\text { 5) Yatıştırma, 6) Ortaklık, 7) Yetki Verme, 8) Vatandaş } \\
\text { Kontrolü }\end{array}$ \\
\hline Hart $(1992,1997)$ & Genç/Çocuk & $\begin{array}{l}\text { Merdiven modeli- } 8 \text { düzey: } \\
\text { 1) Manipülasyon, 2) Dekoratif, 3) Sembolik, 4) Çocuklara } \\
\text { görev ve bilgi verilen, 5) Çocuklara danışılan çocukların } \\
\text { bilgilendirildiği, 6) Yetişkinlerin başlattığı kararların } \\
\text { çocuklarla ortak alındığı, 7) Çocuğun başlatıp yürüttüğü, 8) } \\
\text { Çocuğun başlattığı kararların yetişkinlerle ortak alındığı }\end{array}$ \\
\hline Treseder (1997) & Genç/Çocuk & $\begin{array}{l}\text { Ayrık model- } 5 \text { düzey; } \\
\text { Hiyerarşik olmayan; 1) Atanmış ancak bilgilendirilmiş, } \\
\text { 2) Danışmalı ve bilgilendirilmiş, 3) Yetişkin tarafından } \\
\text { başlatılan çocuklarla paylaşılan, 4) Çocuk tarafından } \\
\text { başlatıllan yetişkinlerle paylaşılan, 5) Çocuk tarafından } \\
\text { başlatılan ve yönlendirilen }\end{array}$ \\
\hline Shier (2001) & Genç/Çocuk & $\begin{array}{l}\text { Matrise gömülü diyagram modeli - } 5 \text { düzey; } \\
\text { 1) Dinleme, 2) Destekleme, 3) Görüşlerini dikkate alma, } \\
\text { 4) Karar verme süreçlerine dâhil etme, 5) Karar vermede } \\
\text { yetki ve sorumluluk paylaşma }\end{array}$ \\
\hline Lardner (2001) & Genç & $\begin{array}{l}\text { Izgara modeli- } 6+6 \text { düzey; } \\
\text { Hiyerarşik olmayan, } 6 \text { yetişkin ve } 6 \text { çocuk düzeyi } \\
\text { tanımlanmış olup, bu iki sütun arasındaki paylaşım modeli }\end{array}$ \\
\hline UNICEF (2001) & Genç & $\begin{array}{l}\text { Stratejik model - Düzey tanımlanmamıs; } \\
4 \text { eksen; Katılımın Düzeyleri, Roller, Coğrafi Etmenler, } \\
\text { Kurumsal Etmenler }\end{array}$ \\
\hline Driskell (2002) & Genç/Çocuk & $\begin{array}{l}\text { Grafik model- Düzey tanımlanmamış; } \\
\text { Hart Merdiveni üzerinden yorumlama: Katılımın } \\
\text { Gerçekleşmediği, Danışma, Sosyal Seferberlik, Katılımın } \\
\text { Gerçekleştiği }\end{array}$ \\
\hline Francis ve Lorenzo (2002) & Çocuk & $\begin{array}{l}7 \text { düzey; } \\
\text { 1) Romantik, 2) Taraflılık, 3) İhtiyaca dayalı, 4) Öğrenme } \\
\text { temelli, 5) Haklara dayalı, 6) Kurumsallaşma, 7) } \\
\text { Çocuklarla birlikte tasarım (Proaktif) }\end{array}$ \\
\hline Fletcher (2003) & Genç & $\begin{array}{l}\text { Merdiven modeli - } 8 \text { düzey; } \\
\text { Hart (1992, 1997)'ın düzeyleri ile aynı, gönüllü esaslı }\end{array}$ \\
\hline IAP2 (2007) & Tümü & $\begin{array}{l}5 \text { düzey; } \\
\text { 1) Bilgilendirme, 2) Danışma, 3) Dahil etme, 4) İşbirliği } \\
\text { yapma, 5) Yetki verme }\end{array}$ \\
\hline Davies (2009) & Genç & $\begin{array}{l}\text { Matris modeli - } 8 \text { düzey; } \\
\text { 1) Manipülasyon, 2) Dekorasyon, 3) Semboliklik, 4) } \\
\text { Görevlerin ve etkinliklerin atanması, 5) Danışılan ve } \\
\text { bilgilendirilen, 6) Yetişkinler tarafindan başlatılan } \\
\text { gençlerle paylaşılan, 7) Gençlerin başlattığı ve yönettiği, 8) } \\
\text { Gençlerin başlattığı yetişkinlerle paylaşıllan }\end{array}$ \\
\hline Shier (2010) & Genç/Çocuk & $\begin{array}{l}\text { Ağaç modeli - Düzey tanımlanmamış; } \\
\text { Ancak aşağıdan yukarıya hiyerarşik bir model önerilmiştir }\end{array}$ \\
\hline Wong ve diğ. (2010) & Genç & $\begin{array}{l}\text { Piramit modeli - } 5 \text { düzey; } \\
\text { 1) Kanal, 2) Sembolik, 3) Çoğulcu, 4) Bağımsız, 5) Özerk }\end{array}$ \\
\hline Davies ve diğ. (2011) & Genç & $\begin{array}{l}\text { Üçgen modeli - } 3 \text { düzey, } 6 \text { alt düzey; } \\
3 \text { düzey: Sağlama, Korunma, Katılım; } \\
6 \text { alt düzey: 1) Dijital vatandaşlığın desteklenmesi, 2) } \\
\text { Gençlerin yetkilendirilmesi, 3) Risklere yanıt verilmesi, 4) } \\
\text { Esnekliğin sağlanması, 5) Pozitif alanların sağlanması, 6) } \\
\text { Gençlerin şekillendirdiği hizmetlerin yaratılması }\end{array}$ \\
\hline Shier (2014) & Çocuk & $\begin{array}{l}3 \text { düzey; } \\
\text { 1) Danışma, 2) İşbirliği, 3) Çocuk liderliğinde }\end{array}$ \\
\hline
\end{tabular}


Şekil: 2

Hart merdiveni (Hart, 1992'dan aktaran "Çocuk katılımının yolları", t.y.).
Hart'ın modelinin etkisi 1995 'te Save the Children tarafından yapılan bir araștırma sonucu kabul görmüştür.

Çocukların katılımı konusunda önemli çalışmaları bulunan Hart (1992), Arnstein'in modelini daha da geliştirerek, genellikle gençlerin ve çocukların katılım merdiveni olarak adlandırılan bir çocuk katılım merdiveni modeli önerisinde bulunmuştur. Çocuk katılım türlerini sekiz basamakta inceleyen Hart, birinci, ikinci ve üçüncü basamakları "katılımın gerçekleşmediği" tipler olarak göstermektedir. Şekil 2'de çocukların yetişkinlerle çalışması ile gelişen işbirliği seviyelerine göre farklı katılım düzeylerini gruplandiran "Hart Merdiveni" görülmektedir.
Katılım düzeylerinin Arnstein ve Hart'ın merdivenindeki gibi bir hiyerarşiye bağlı olmadığını ve hangi aşamanın veya düzeyin seçileceğinin önerilen projeye ve çocukların isteklerine bağlı olduğunu savunan görüşler de bulunmaktadır. Ancak yine de tüm aşamalardaki hedefler, Arnstein ve Hart'ın çalışmaları ile benzerlik taşımaktadir.

Literatürde tanımlanan farklı katılım modellerinin ortak özelliği, çocukların ve gençlerin karar verme süreçlerine etkileri arttıkça katılım düzeyinin de yükselmesidir. Bu modellerde ve süreçlerde; katılımın farklı düzeylerde gerçekleşmesinin, temelde projedeki katılım sürecinin çocukları ne kadar dâhil etmeyi amaçladığı, katılım

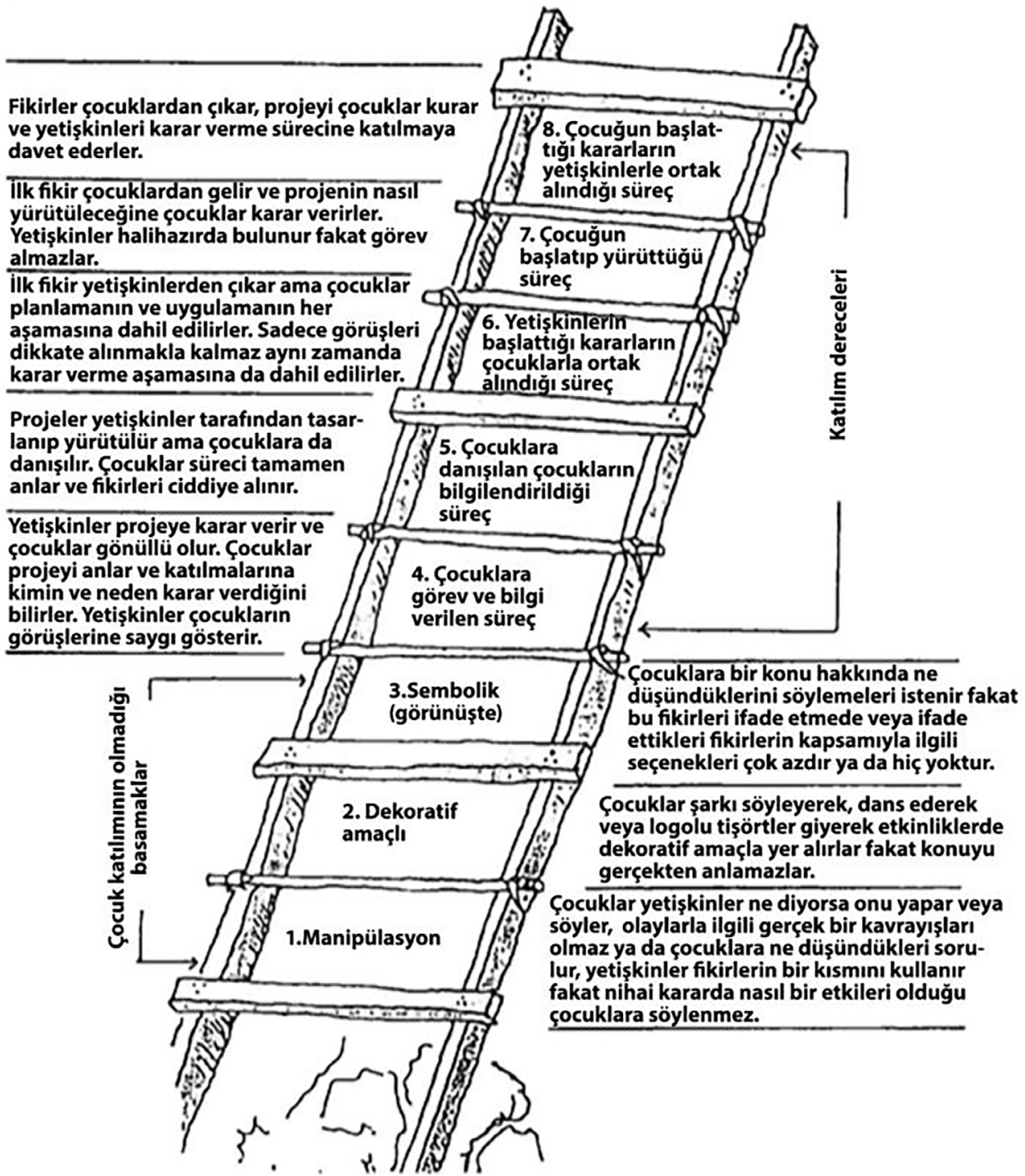


sürecinin şeffaflığı ve netliği, çocuklar tarafından alınan kararların, belirtilen görüşlerin ya da getirilen önerilerin karar verme sürecinde ne düzeyde etkili olduğu ve katılım sürecinde güç-yetki dağı̆lımının nasıl yapıldığı ile yakından ilişkili olduğu görülmektedir.

\section{Açık Kamusal Mekân Tasarımına Cocukların Katılımında Kullanılan Yöntemler}

Açık kamusal mekân tasarımında çocukların katılımının sağlanması katılım yöntemleri ile doğrudan ilişkilidir. Katılım süreçlerinin algılanışındaki farklılıklar ve farklı düzeylerde katılım sağlama amaçları, katılım yöntemlerinde de çeşitliliğe neden olmuştur. Literatürde tanımlanmış olan farklı yöntemler olmakla birlikte, çocuk katılımında kullanılan yöntemlerin gerçekleştirilecek projenin konusu, süreci, projenin gerçekleştiği bölgenin kültürü ve çocukların yaş aralığı gibi birçok etkene göre çeşitlendiği görülmektedir.

Çocuklarla gerçekleştirilen proje süreçlerinde kullanılan katılım yöntemleri, proje süreçleri boyunca farklılık göstermelidir. Literatürde tanımlanmış olan farklı yöntemler olmakla birlikte, çocukların katılımında kullanılan yöntemler; harita çalışmaları (davranıș ve toplum haritaları), alan araştırma çalışmaları (röportaj ve anket çalışmaları), günlük aktivite çizelgeleri (geziler, fotoğraf çekimi), çizim ve kolaj çalışmaları (bireysel/ortak çizimler, kolaj çalışmaları, slayt çalışmaları), maket çalışmaları (maket ve simülasyonlar), medya ve iletişim araçları (basılı yayın çalışmaları, video/ radyo/ televizyon, toplumsal etkinlikler), oyunlaştırma (masa oyunlarl, rol yapma/ tiyatro) ve grup etkileşim yöntemleri (odak gruplar, çalıştaylar) atölyeler) olarak sınıflandırılabilir.

Katılım yöntemlerinin doğru seçimi doğrultusunda çocuklar için katılımcı bir süreç oluşabilecektir. Katılımcı süreçlerde yapılması gereken, çocuklara en uygun yöntemlerin tercih edilmesidir. Başarılı bir çalışma her aşaması planlı bir katılım sürecine bağlıdır. Doğru tasarlanan bir süreç, sorunların belirlenmesine, önerilerin getirilmesine, istenilen ürünün elde edilmesine ve katılımcıların etkin bir şekilde sürece dâhil edilmesine olanak verecektir.

\section{Açık Kamusal Mekân Tasarımında Çocuk Katılım Yöntemlerinin Etkinlik Düzeyi Değerlendirme Kriterleri}

Çocuklar için başarılı bir projenin gerçekleştirilmesi, başarılı ve etkili bir katılım sürecinin kurgulanması ve yönetilmesi ile yakından ilişkilidir. Sürecin başarısında katılımı sağlamak amacıyla kullanılan yöntemlerin etkinliği de büyük bir öneme sahiptir. Bu çalışma, çocuklar için farklı katılım yöntemlerinin etkinliğinin değerlendirilebilmesine ilişkin kriterlerin belirlenmesini amaçlamaktadır.

Katılım sürecinin değerlendirmesine dair literatürde yapılmış çeşitli çalışmalar ya da katılım sürecini uygulayan kurum ve kuruşlar tarafından yayınlanan birtakım standartlar olsa da yapılan literatür taraması sonucunda, katılım yöntemlerinin uygulamadan sonraki etkinliklerini ölçmeye yönelik standart bir yöntemin geliştirilememiş olduğu görülmektedir. Literatürde tanımlanmış farklı kriterler bulunsa da, katılım yöntemlerinin etkinliğini değerlendirebilecek net yaklaşımlar geliştirilememiştir.

Yapılan literatür araştırması sonucunda oluş̧urulan Tablo 2'de katılım yöntemlerinin etkinlik düzeyi değerlendirmesine yönelik farklı kriterlerin tanımlandığ 1 görülmüşse de; çocuk katılımının etkinliğinin değerlendirmesine yönelik literatürün oldukça yetersiz olduğu söylenebilmektedir.

Literatürde yapılan araştırmalarda bazı araştırmacıların kriter dizinlerinin yanı sira, uygulama standartları ya da uygulama boyutları tanımladıkları da görülmüştür. Ancak literatürde çocuk katılımının etkinliğini değerlendirmeye yönelik olarak belirlenen kriterlerin genellikle Çocuk Haklarına Dair Sözleşmenin ilgili maddeleri esas alınarak oluşturulduğu gözlemlenmiştir. Katılımın etkin ve anlamlı olması için, münferit, tek seferlik bir etkinlik olarak değil, bir süreç olarak anlaşılması gerekir (UNCRC, 2009). Bu çalışma da katılımın sağlanmasını bir amaç olarak görmemekte, belirlenen hedeflere ulaşmada bir araç olarak ele almaktadır. Belirlenen amaçlara ulaşmak için planlanan katılım süreçle- 


\begin{tabular}{|l|l|}
\hline Referans & Kriterler \\
\hline Treseder (1997) & $\begin{array}{l}5 \text { kriter: (1) Güce erişim, (2) İlgili bilgilere erişim, (3) Farklı seçenekler arasında gerçek seçimler olması gerektiği, (4) } \\
\text { Güvenilir, bağımsı kişiden destek alınması gerektiği, (5) İtiraz ve şikâyet aracının olması }\end{array}$ \\
\hline Rowe ve Frewer (2000) & $\begin{array}{l}\text { 3 boyut: a) Kapsam, b) Süreç, c) Sonuç. } \\
9 \text { kriter: (1) Temsiliyet, (2) Bağımsızlı ve tarafsızlık, (3) Katılım aşaması, (4) Karara etki, (5) Şeffaflık, (6) Kaynaklara } \\
\text { erişim, (7) Beklentilerin netliği, (8) Karar verme sürecinin yapılanması ve izlenmesi, (9) Maliyet verimliliği. }\end{array}$ \\
\hline Driskell (2002) & $\begin{array}{l}12 \text { kriter: (1) Yerel, (2) Şeffaf, (3) Kapsayıcı, (4) İnteraktif, (5) Duyarlı, (6) İlgili, (7) Eğitimsel, (8) Yansıtıcı, (9) } \\
\text { Dönüştürücü, (10) Sürdürülebilir, (11) Kişisel, (12) Gönüllü }\end{array}$ \\
\hline Save the Children (2005) & $\begin{array}{l}7 \text { kriter: (1) Etik bir yaklaşım: şeffaflık, dürüstlük ve hesap verebilirlik, (2) Çocukların katıllımının ilgili ve gönüllü } \\
\text { olması, (3) Çocuk dostu çevre sağlama, (4) Fırsat eşitliği, (5) Yetişkinin etkili ve kendinden emin olması, (6) Katılımın, } \\
\text { çocukların güvenliğini ve korunmasını teşvik etmesi, (7) Takip ve değerlendirmenin sağlanması. }\end{array}$ \\
\hline UNCRC (2009, 2014) & $\begin{array}{l}9 \text { kriter: (1) Şeffaf ve bilgilendirici, (2) Gönüllü, (3) Saygıll, (4) İlgili, (5) Çocuk dostu, (6) Kapsayıcı, (7) Eğitim ile } \\
\text { desteklenmiş, (8) Emniyetli ve riske duyarlı, (9) Hesap verebilir. }\end{array}$ \\
\hline Crowley ve Skeels (2010) & $\begin{array}{l}\text { 7 kriter: (1) bilgi, (2) tercih edebilirlik, (3) ayrım gözetmeme, (4) saygı, (5) çıkarımda bulunma, (6) geribildirim, (7) } \\
\text { geliştirme. }\end{array}$ \\
\hline Shier (2014) & $\begin{array}{l}\text { 3 boyut: a) Kapsam, b) Kalite, c) Sonuç. } \\
9 \text { kriter: (1) Seffaf ve bilgilendirici, (2) Gönüllü, (3) Saygıllı, (4) Uygun, (5) Çocuk dostu, (6) Kapsayıcı, (7) Eğitim ile } \\
\text { desteklenmiş, (8) Güvenli ve hassas, (9) Hesap verebilir. }\end{array}$ \\
\hline
\end{tabular}

Tablo: 2

Literatürde tanımlanmış değerlendirme kriterleri. rinde kullanılan yöntemlerin etkinliğinin belirlenmesi gelecekte daha etkili katılım süreçlerinin planlanmasında kolaylık sağlayacaktır.

Çalışma kapsamında, çocukların katılımının sağlandığı projelerdeki katılım süreçleri dahilinde, bu yöntemlerin etkinliğinin değerlendirilmesine yönelik kriterler dizini belirlenmeden önce, genel olarak bu yöntemlerden beklentinin ne olduğuna yönelik olarak şu sorular tanımlanmıştır; $\mathrm{Bu}$ yöntemle çocuklar karar verme süreçlerine dahil olmuşlar mıdır? Bu yöntemle çocuklar mekanın tasarımına yönelik kararlara dahil olmuşlar mıdır? Bu yöntemle projeye erken katılım sağlanmış mıdır? Bu yöntem uygulanırken kaynaklara erişim yeterli düzeyde sağlanmış mıdır? Bu yöntem katılım ve karar verme süreçlerinde şeffaflık ilkesiyle uygulanmış mıdır? Bu yöntemle çocuklar zorunlu tutulmayarak süreçteki etkinlikleri gönüllülük esasıyla yürütülmüş müdür? Bu yöntemle çocuk dostu ortamlar yaratılmış mıdır? Bu yöntemle tasarımdan etkilenecek farklı yaş grubu, cinsiyeti, engel durumu vb. tüm çocukları kapsayan bir katılımcı profili sürece dahil edilmiş midir? Bu yöntemle çocukların katılımını kolaylaştırmak için ihtiyaç duyulan bilgi, beceri ve eğitim desteği sağlanmış mıdır? $\mathrm{Bu}$ yöntemin sonunda geribildirimler toplanmış mıdır?

Bu sorulara cevap vermek amacıyla; çalışma kapsamında incelenen farklı etkinlik değerlendirme kriter dizinleri ve yöntemleri doğrultusunda, açık kamusal mekan tasarımında kullanılan katılım yöntemlerinin etkinliğinin değerlendirilmesine yönelik on kriter tanımlanmıştır. Bunlar; (1) karara etki, (2) tasarıma etki, (3) katılım aşamaS1, (4) kaynaklara erişim, (5) şeffaflık, (6) gönüllülük, (7) çocuk dostu, (8) kapsayıc1lik, (9) eğitim ile desteklenme ve (10) hesap verebilirlik kriterleri olarak belirlenmiştir.

Karara Etki kriteri, uygulanan yöntem sonucunda elde edilen sonuçların kararlara ne kadar yansıtıldığını değerlendirmeye yöneliktir. Yöntemin sonuçlarının, kararlara doğrudan etkisi arttıkça yöntemin etkinliği de artmaktadır (Rowe ve Frewer, 2000). Bu kriter değerlendirilirken, katılımcı çocuklarla gerçekleştirilen tüm katılım yöntemlerinden elde edilen çıktıların, kararlara yansitılabileceği dikkate alınarak, çocukların karar ürettiği yöntemlerin etkinliğinin sağlandığ kabul edilmiştir. Aynı zamanda yöntemler sonucu elde edilen çıktıların kararlara nasıl yansıtıldığının çocuklarla paylaşılması ve üzerinde istişarelerin gerçekleştirilmesi oldukça önemlidir.

Tasarıma Etki kriteri, kullanılan yöntemin, katılımcı çocukların yalnızca fikir vererek ya da katılımcı çocuklara danışılarak değil, fiziksel mekânın tasarımına dair kararlar üreterek katılım gösterebilmeleri üzerinden bir değerlendirme yapabilmek için belirlenmiştir. 
Katılım Aşaması kriteri, çocukların karar alma sürecine hangi aşamada dâhil edildiğini değerlendirilmeye yöneliktir. Çocukların katılım sürecine olabildiğince erken aşamalarda dâhil edilmesinin kullanılan yöntemin etkinliğini artırıcı olacağı düşünülmektedir.

Kaynaklara Erişim kriteri, yöntemin çocuklara gerekli bilgiyi, profesyonel desteği, gerekli malzeme ve uygun zamanı sağlayabilmesi üzerinden bir değerlendirme yapmaya yöneliktir.

Şeffaflık kriteri, literatürde tanımlanmış etkinlik değerlendirme kriterleri arasında yaygın olarak kullanılan kriterlerden biri olup, çocukların sürecin tüm aşamalarını ve kararların nasıl alındığını görebildiği, katılımın nasıl gerçekleşeceği, kapsamı, amacı ve etkisi konusunda tam, erişilebilir, farklılıklara duyarlı ve yaşlarına uygun bilgilendirmenin sağlandığı, çocukların fikir ve görüşlerini özgürce ifade edebildiği yöntemlerin etkinliğini ölçmeye yöneliktir. Katılım sürecinin şeffaflığı, çocukların projeye ve sürece olan güvenini artırıcı bir etmen olmakla birlikte, çocukların katılım süreci için istekli olmalarını da sağlayacak bir etmendir.

Gönüllülük kriteri, kullanılan yöntemin çocukların istekleri dışında görüşlerini ifade etmeye zorlanmadan ve istedikleri aşamada bu yönteme katılmaktan vazgeçebileceklerinin farkındalığıyla gerçekleştirilmesi potansiyelini değerlendirmeyi amaçlamaktadır.

Çocuk Dostu kriteri, yöntemlerin çocukların yaşlarına ve gelișen kapasitelerine uygun olarak geliştirilmesi potansiyelini değerlendirebilmeye yöneliktir. Çocukların sürece etkin katılımlarının sağlanmasında, kullanılan yöntemin yaşlarına, kimlik gelişimlerine, kültürlerine ve gelişen kapasitelerine göre analiz edilerek belirlenmesi önemlidir.

Kapsayıcılık kriteri, literatürde tanımlanmış etkinlik değerlendirme kriterleri arasinda yaygın olarak kullanılan kriterlerden biridir. Kapsayıcılık kriteri, yöntemlerin katılım sürecinde etkilenecek çocukların yaş, cinsiyet, 1rk, din, dil, engel durumu gözetmeksizin tümünün dâhil edilebilme- sini, ayrım gözetmeksizin firsat eşitliğini sağlayabilmesini ve kültürel olarak duyarlı olabilmesini değerlendirmeye yönelik olarak belirlenmiştir. Katılım süreçlerine, alınacak kararlardan etkilenecek çocukların tümünü temsil edecek katılımcıların dâhil edilmesi oldukça önemlidir.

Eğitim ile Desteklenme kriterinde, yöntemin çocukların sürece katılımlarını kolaylaştıracak hazırlık, bilgi ve beceri ihtiyacının eğitim ile sağlanmasının değerlendirmesini amaçlanmaktadır.

Hesap Verebilirlik kriterinde, kullanılan yöntemin her aşamasında çocukların fikir ve görüşlerinin nasıl yorumlandığına ve kullanıldığına ilişkin olarak geribildirimlerin sağlanabilmesinin değerlendirilmesi amaçlanmaktadır. Çocukların katılım sürecinin mümkün olduğunca çocuklar ile birlikte izlenmesi ve değerlendirmesinin, yöntemin etkinliğini artıracağı düşünülmektedir.

Literatür referans alınarak belirlenen kriterlerin değerlendirmesi, örnek projelerde kullanılan katılım yöntemlerinin uygulama süreçlerinde kriterleri sağlayıp sağlamadığı üzerinden yapılacaktır.

\section{Uygulama Örnekleri Üzerinden Çocuk Katılım Yöntemlerinin Etkinlik Düzeyi Değerlendirmesi}

Çocuğun fiziksel çevresinin ilk basamağ olan konut yakın çevresi; bir sonraki oyun ağı olan sokaklar ve meydanlar; günlerinin çoğunu geçirdikleri okul bahçeleri ve onlara mekâna ait olma hissini en çok yansıtan çocuk oyun alanları ve parklar oldukça önemlidir. Bu nedenle uygulama örneklerinin seçiminde; farklı açık alan özelliği göstermeleri (park, meydan, okul bahçesi vb.), farklı ölçeklerde gerçekleştirilmiş olmaları, farklı kullanıcı profillerine sahip projeler olmaları ve katılımcı bir süreç ile tasarlandıkları ve uygulandıkları için ödüller kazanmış projeler olmaları etkili olmuştur. Çalışma kapsamında yapılan araștırma sürecinde ülkemizde çocukların katılımlarının sağlandı ̆̆ı uygulama örneklerinin oldukça yetersiz olduğu gözlemlenmiştir. Bu nedenle açık kamusal mekân özelliği gösteren, farklı yöntemler kullanılarak ka- 
Şekil: 3

Çocukların katılımlarının sağlandı̆̆ uygulama örnekleri. tılımcı süreçlerle tasarlanmış ve uygulanmış olan, ülkemizden bir adet olmak üzere toplamda altı adet uygulama örneği ele alınmıştır. Bu örnekler Yeni Zelanda'dan Freyberg Meydanı Projesi, Avustralya'dan Kellyville Okul Bahçesi Projesi, ABD’den Boulder Civic Area Park Projesi, Avustralya'dan Fremantle Esplanade Gençlik Meydanı Projesi, Hollanda'dan Avonturis Doğa Oyun Alanı Projesi ve Türkiye'den Oyun Engel Tanımaz Parkı Projesidir (Şekil 3). Şekil 4'te proje künyelerine yer verilmiştir. Uygulama örneklerinde kullanılan yöntemlerin etkili olup olamadıklarını incelemeden önce, literatür araştırmalarında bahsedilen katılım yöntemleri ve örnek projelerde uygulanan yöntemler referans alınarak katılım yöntemleri listesi oluşturulmuştur. Katılım yöntemleri listesi oluşturulurken literatürde tanımlanmış ve uygulama örneklerinde yaygın olarak kullanılan yöntemler olmasına dikkat edilmiştir. Ayrıca literatür ve uygulama örnekleri üzerinden yapilan incelemelerde yetişkinlerde kullanılan katılım yöntemlerinin çocuklar için de geçerli olduğu görüldüğünden, katılım yöntemleri listesi oluşturulurken bu durum da dikkate alınmiştır.

Bu kapsamda oluşturulan listede yer alan katılım yöntemleri; alan gezisi, fotoğraflama, anket, odak grup tartışması, çalıştay/ atölye, haritalama, çizim ve kolaj, maket, oyunlaştırma, internet tabanlı katılım ve
Şekil: 4

Çocukların katılımlarının sağlandığı uygulama örnekleri proje künyeleri.
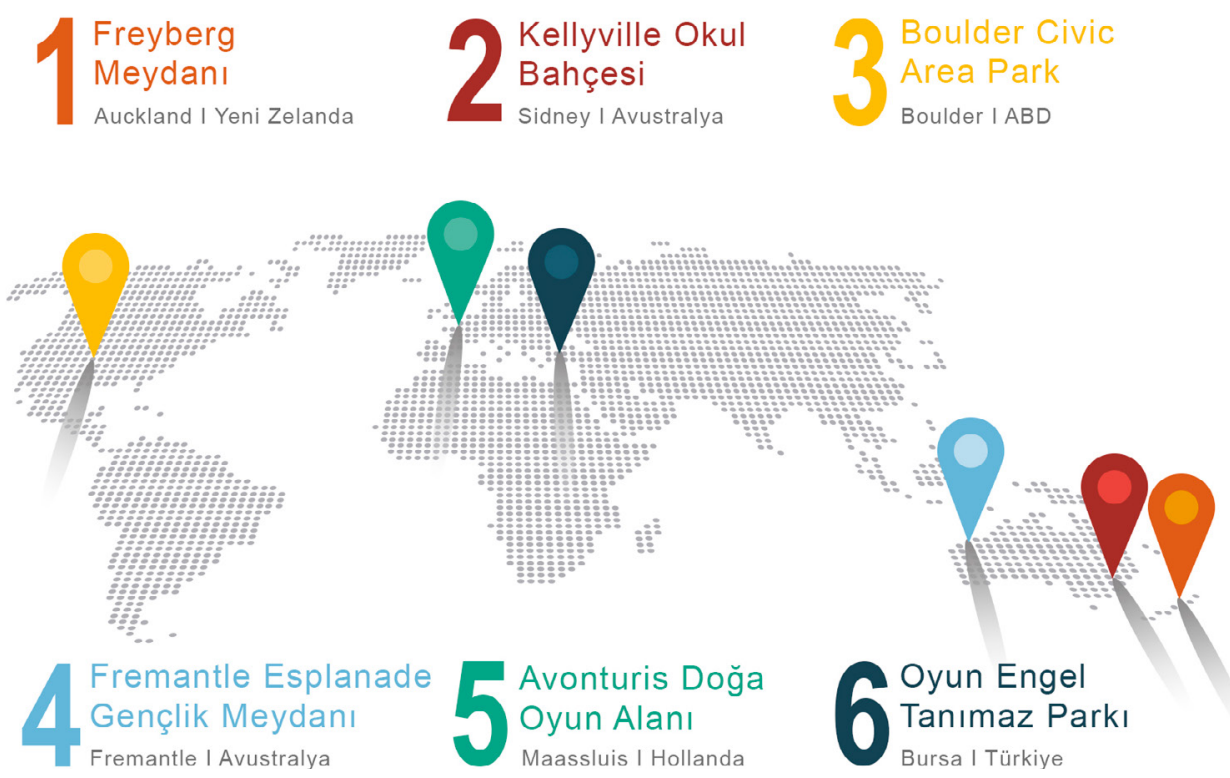
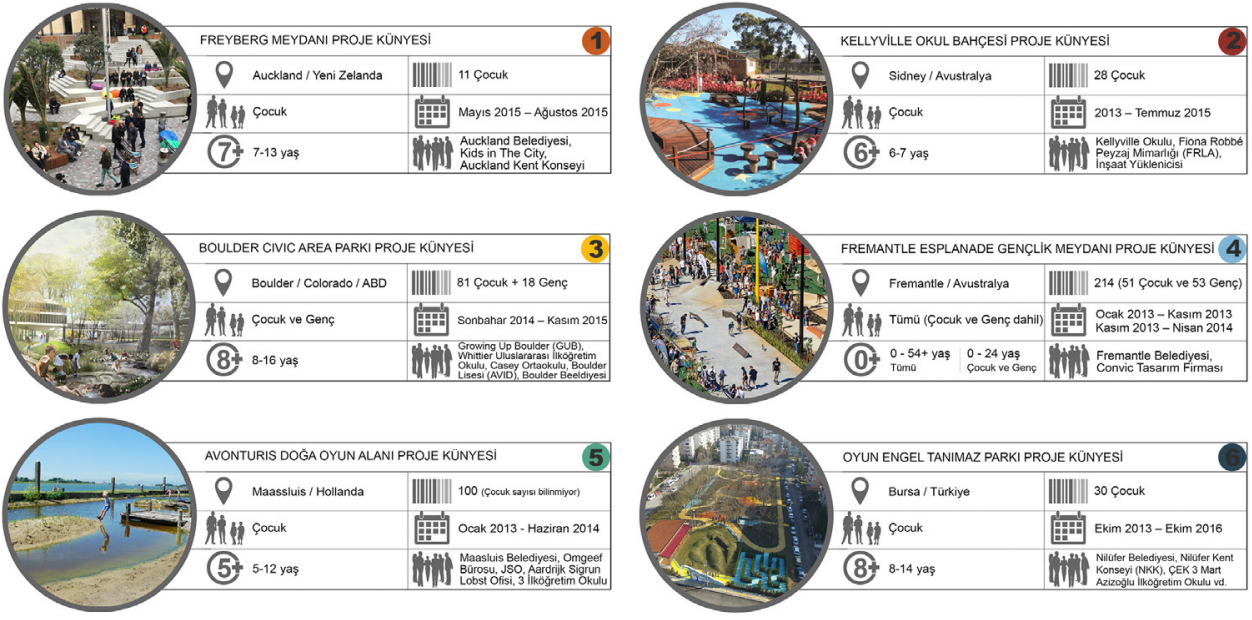
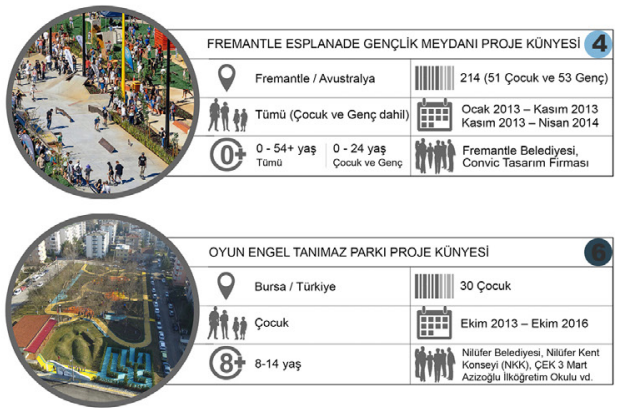


\begin{tabular}{|l|c|c|c|c|c|c|}
\hline Katılım Yöntemi & $\begin{array}{c}\text { Freyberg } \\
\text { Meydanı }\end{array}$ & $\begin{array}{c}\text { Kellyville Okul } \\
\text { Bahçesi }\end{array}$ & $\begin{array}{c}\text { Boulder Civic } \\
\text { Area Park }\end{array}$ & $\begin{array}{c}\text { Fremantle } \\
\text { Esplanade } \\
\text { Gençlik Meydanı }\end{array}$ & $\begin{array}{c}\text { Avonturis Doğa } \\
\text { Oyun Alanı }\end{array}$ & $\begin{array}{c}\text { Oyun Engel } \\
\text { Tanımaz Parkı }\end{array}$ \\
\hline Alan gezisi & + & + & + & - & - & - \\
\hline Fotoğraflama & + & - & + & - & + & + \\
\hline Anket & + & - & + & + & + & + \\
\hline Odak Grup Tartışması & + & + & + & + & + & + \\
\hline Çalıştay/ Atölye & + & + & + & + & + & + \\
\hline Haritalama & + & - & + & + & + & + \\
\hline Çizim ve Kolaj & + & + & + & + & + & + \\
\hline Maket & - & - & + & + & + \\
\hline Oyunlaştırma & - & - & - & + & + \\
\hline $\begin{array}{l}\text { İnternet Tabanlı } \\
\text { Katılım }\end{array}$ & - & - & - & + & + \\
\hline Medya ve İletişim & - & + & + & + & + \\
\hline
\end{tabular}

medya ve iletişim yöntemleridir. Alan gezisi, fotoğraflama, anket, haritalama, çizim ve kolaj, maket, oyunlaştırma ve medya ve iletişim yöntemleri, çocuk katılım yöntemleri için literatürde de yaygın olarak ele alındığından bu çalışma kapsamında katılım yöntemleri olarak belirlenmiştir. Yetişkinlerde sıklıkla kullanılan katılım yöntemlerinden olan odak grup tartışması ve çalıştay/atölye yöntemleri ise örnek projelerde kullanılan yaygın yöntemler arasında olmaları nedeniyle katılım yöntemleri listesine eklenmiştir. İnternet tabanlı katılım yöntemi ise çocuklar için literatürde tanımlanan yöntemler arasında bulunmamakta olup, örnek proje süreçlerinde de sadece yetişkin kontrolünde yapılan çevrimiçi anketler kapsamında başvurulan bir yöntem olmuştur. İnternet kullanımının giderek yaygınlaşması ve çocuk katılımında tamamen çocuk liderliğinde kullanılmasa da katılım yöntemlerinde sıklıkla kullanılan bir yöntem haline gelmesi nedeniyle, internet tabanlı katılım yöntemi de listeye eklenmiştir.

Çalışma kapsamında belirlenen 11 katılım yönteminden; Freyberg Meydanı projesinde 7 yöntem, Kellyville Okul Bahçesi projesinde 5 yöntem, Boulder Civic Area Park projesinde 9 yöntem, Fremantle Esplanade Gençlik Meydanı projesinde 6 yöntem, Avonturis Doğa Oyun Alanı projesinde 3 yöntem ve Oyun Engel Tanımaz Parkı projesinde 10 yöntem kullanılmıştır. $\mathrm{Bu}$ yöntemlerin kriterlere göre etkinlikleri uygulama örnekleri üzerinden değişkenlik göstermektedir.

Tanımlanan etkinlik düzeyi değerlendirilmesi kriterleri doğrultusunda, yöntemlerin etkinliklerinin değerlendirilmesi için, çalışma kapsamında belirlenen katılım yöntemlerini kapsayan satırlar ve etkinlik değerlendirme kriterlerini içeren sütunlardan oluşan matrisler oluşturulmuştur. Matrisler her bir örnek proje için oluşturularak, projede kullanılan katılım yöntemlerinin kriterler bakımından etkinliklerinin değerlendirmeleri yapılmıştır. Yöntemlerin etkinlik değerlendirme kriterleri çerçevesinde incelendiği matrislerde, yöntemlerin her kriter açısından etkinlik düzeyi (0) ve (1) şeklinde iki değer ile derecelendirilmiştir. (0) değeri yöntemin kriter açısından değerlendirilme şartlarını sağlamadığı durumlarda ve (1) değeri ise yöntemin bu kriteri sağladığı durumlarda kullanılmıştır.

Katılım kavramı bir süreci ifade ettiğinden ve katılım sürecinde farklı yöntemlerin bir arada kullanılmasıyla birlikte etkin katılım gerçekleşebileceğinden, örnek projelerde kullanılan yöntemlerin her birinin belirlenen on etkinlik değerlendirme kriterine göre derecelendirilmesinin ardından, matriste her bir örnek projenin belirlenen kriterler üzerinden aldığı toplam değerler esas alınarak grafikler oluşturulmuş ve projelerin etkinliği irdelenmeye çalışılmıştır. Uygulama örnekleri üzerinden yapılan genel değerlendirme Tablo 4'te yer almaktadır.
Tablo: 3

Örnek projelerde kullanilan katılım yöntemleri.

Tablo: 4

Uygulama örnekleri üzerinden genel değerlendirme. 


\begin{tabular}{|c|c|c|c|}
\hline Örnekler & Katılım Yöntemi & Yaș Grubu & Değerlendirme \\
\hline Freyberg Meydanı & $\begin{array}{l}\text { Belirlenen } 11 \text { katılım } \\
\text { yönteminden } 7 \text { yöntem } \\
\text { kullanılmıştır. } \\
\text { Bu yöntemler: } \\
\text { - alan gezisi, } \\
\text { - fotoğraflama, } \\
\text { - anket, } \\
\text { - odak grup tartışması, } \\
\text { - harişay/atölye, } \\
\text { - çizim ve kolaj } \\
\text { yöntemleridir. }\end{array}$ & $\begin{array}{l}7-13 \text { yaş } \\
11 \text { çocuk } \\
\text { (Engelli çocuklar } \\
\text { da dahil) }\end{array}$ & $\begin{array}{l}\text { Katılım yöntemlerinin etkinlik düzeyi değerlendirmesinde; } \\
\text { - Çalıştay/äölye, çizim ve kolaj, odak grup tartışması yöntemleri kriterleri } \\
\text { en çok sağlayan yöntemlerdir. } \\
\text { - Kriterleri en az sağlayan yöntem ise; haritalama yöntemidir. } \\
\text { - Karara etki eden yöntemler: anket, odak grup tartışması, çalıştay/atölye, } \\
\text { haritalama, çizim ve kolaj yöntemleridir. } \\
\text { - Tasarıma etki eden yöntemler: çalıştay/atölye, çizim ve kolaj } \\
\text { yöntemleridir. } \\
\text { - Projede kullanılan yöntemlerin tasarıma etki konusunda oldukça zayıf } \\
\text { kaldığı söylenebilir. } \\
\text { - Eğitim ile desteklenme kriteri ise sağlanamamıştır. }\end{array}$ \\
\hline $\begin{array}{l}\text { Kellyville Okul } \\
\text { Bahçesi }\end{array}$ & $\begin{array}{l}\text { Belirlenen } 11 \text { katılım } \\
\text { yönteminden } 5 \text { yöntem } \\
\text { kullanılmıştır. Bu yöntemler: } \\
\text { - alan gezisi, } \\
\text { - odak grup tartışması, } \\
\text { - çalıştay/atölye, } \\
\text { - çizim ve kolaj, } \\
\text { - medya ve iletişim } \\
\text { yöntemleridir. }\end{array}$ & $\begin{array}{l}\text { 6-7 yaş } \\
28 \text { çocuk }\end{array}$ & $\begin{array}{l}\text { Katılım yöntemlerinin etkinlik düzeyi değerlendirmesinde; } \\
\text { - Çizim ve kolaj, odak grup tartışması yöntemleri kriterleri en çok sağlayan } \\
\text { yöntemlerdir. } \\
\text { - Kriterleri en az sağlayan yöntem ise; alan gezisi yöntemidir. Çalıştay/ } \\
\text { atölye ve medya ve iletişim yöntemlerinin de çok etkili olduğu } \\
\text { söylenememektedir. } \\
\text { - Karara ve tasarıma etki eden yöntemler: odak grup tartışması, çalıştay/ } \\
\text { atölye, çizim ve kolaj yöntemleridir. } \\
\text { - Projede kullanılan yöntemlerin tasarıma etki, katılım aşaması ve } \\
\text { gönüllülük konusunda zayıf kaldığı söylenebilmektedir. Eğitim ile } \\
\text { desteklenme ve kapsayıcılık kriterleri sağlanamamıştır. }\end{array}$ \\
\hline $\begin{array}{l}\text { Boulder Civic } \\
\text { Area Park }\end{array}$ & $\begin{array}{l}\text { Belirlenen } 11 \text { katılım } \\
\text { yönteminden } 9 \text { yöntem } \\
\text { kullanılmıştır. Bu yöntemler: } \\
\text { - alan gezisi, } \\
\text { - fotoğraflama, } \\
\text { - anket, } \\
\text { - odak grup tartışması, } \\
\text { - çalıştay/atölye, } \\
\text { - haritalama, } \\
\text { - çizim ve kolaj, } \\
\text { - oyaket, } \\
\text { yöntemleştırma } \\
\end{array}$ & $\begin{array}{l}8-16 \text { yaş } \\
81 \text { çocuk, } \\
18 \text { genç } \\
(8-9 \text { yaş } \\
60 \text { çocuk, } \\
12-14 \text { yaş } \\
21 \text { çocuk, } \\
16 \text { yaş } \\
18 \text { genç) } \\
\text { (Engelli çocuklar } \\
\text { da dahil) }\end{array}$ & $\begin{array}{l}\text { Kat1lım yöntemlerinin etkinlik düzeyi değerlendirmesinde; } \\
\text { - Çizim ve kolaj, haritalama, çalıştay/atölye ve oyunlaştırma yöntemleri } \\
\text { kriterleri en çok sağlayan yöntemlerdir. Odak grup tartışması ve maket } \\
\text { yöntemleri de oldukça etkili yöntemler olmuşlardır. } \\
\text { - Kriterleri en az sağlayan yöntemler ise; alan gezisi ve fotoğraflama } \\
\text { yöntemleridir. } \\
\text { - Karara etki eden yöntemler: odak grup tartışması, çalıştay/atölye, } \\
\text { haritalama, çizim ve kolaj, maket ve oyunlaştırma yöntemleridir. } \\
\text { - Tasarıma etki eden yöntemler: anket, odak grup tartışması, çalıştay/atölye, } \\
\text { haritalama, çizim ve kolaj, maket ve oyunlaştırma yöntemleridir. } \\
\text { - Projede kullanılan yöntemlerin hiçbiri eğitim ile desteklenme kriterini } \\
\text { sağlamamaktadır. }\end{array}$ \\
\hline $\begin{array}{l}\text { Fremantle } \\
\text { Esplanade Gençlik } \\
\text { Meydanı }\end{array}$ & $\begin{array}{l}\text { Belirlenen } 11 \text { katılım } \\
\text { yönteminden } 6 \text { yöntem } \\
\text { kullanılmıştır. Bu yöntemler: } \\
\text { - anket, } \\
\text { - odak grup tartışması, } \\
\text { - çalıștay/atölye, } \\
\text { - çizim ve kolaj, } \\
\text { - inaket, } \\
\text { yönternet tabanlı katılım } \\
\end{array}$ & $\begin{array}{l}0-24 \text { yaş } \\
51 \text { çocuk, } \\
53 \text { genç } \\
(0-11 \text { yaş } \\
1 \text { çocuk, } \\
12-18 \text { yaş } 50 \\
\text { çocuk, } 19-24 \text { yaş } \\
53 \text { genç) }\end{array}$ & $\begin{array}{l}\text { Katılım yöntemlerinin etkinlik düzeyi değerlendirmesinde; } \\
\text { - Kullanılan yöntemlerin tamamı: kriterlerin biri dışında tüm kriterleri } \\
\text { sağlamaktadır. } \\
\text { - Kullanılan tüm yöntemler karara ve tasarıma etki eden yöntemler } \\
\text { olmuşlardır. } \\
\text { - Projede kullanılan yöntemlerin hiçbiri eğitim ile desteklenme kriterini } \\
\text { sağlamamaktadır. }\end{array}$ \\
\hline $\begin{array}{l}\text { Avonturis Doğa } \\
\text { Oyun Alanı }\end{array}$ & $\begin{array}{l}\text { Belirlenen } 11 \text { katılım } \\
\text { yönteminden } 3 \text { yöntem } \\
\text { kullanılmıştır. Bu yöntemler: } \\
\text { • odak grup tartı̧̧ması, } \\
\text { • çalıştay/atölye, } \\
\text { • çizim ve kolaj } \\
\text { yöntemleridir. } \\
\end{array}$ & $\begin{array}{l}\text { 5-12 yaş çocuk } \\
\text { Toplam: } \\
100 \text { katılımcı } \\
\text { (Engelli çocuklar } \\
\text { dahil) }\end{array}$ & $\begin{array}{l}\text { Katılım yöntemlerinin etkinlik düzeyi değerlendirmesinde; } \\
\text { • Kullanılan yöntemlerin tamamı kriterlerin tümünü sağlamaktadır. } \\
\text { - Kullanılan tüm yöntemler karara ve tasarıma etkili olmuştur. }\end{array}$ \\
\hline $\begin{array}{l}\text { Oyun Engel } \\
\text { Tanımaz Parkı }\end{array}$ & $\begin{array}{l}\text { Belirlenen } 11 \text { katılım } \\
\text { yönteminden } 10 \text { yöntem } \\
\text { kullanılmıştır. Bu yöntemler: } \\
\text { - alan gezisi, } \\
\text { - fotoğraflama, } \\
\text { - anket, } \\
\text { - odak grup tartışması, } \\
\text { - çalıștay/atölye, } \\
\text { - haritalama, } \\
\text { - çizim ve kolaj, } \\
\text { - maket, } \\
\text { - oyunlaştırma, } \\
\text { yöntema ve iletişim } \\
\text { onteridir. }\end{array}$ & $\begin{array}{l}8-14 \text { yaş } \\
30 \text { çocuk } \\
\text { (Engelli çocuklar } \\
\text { da dahil) }\end{array}$ & $\begin{array}{l}\text { Katılım yöntemlerinin etkinlik düzeyi değerlendirmesinde; } \\
\text { - Odak grup tartışması, çizim ve kolaj, haritalama, çalıştay/atölye } \\
\text { yöntemleri kriterlerin tamamını sağlayan yöntemlerdir. Alan gezisi ve } \\
\text { maket de oldukça etkili yöntemler olmuşlardır. } \\
\text { - Kriterleri en az sağlayan yöntem ise; anket ve medya iletişim yöntemidir. } \\
\text { - Karara etki eden yöntemler: alan gezisi, odak grup tartışması, çalıştay/ } \\
\text { atölye, haritalama, çizim ve kolaj, maket yöntemleridir. } \\
\text { - Tasarıma etki eden yöntemler: odak grup tartışması, çalıştay/atölye, } \\
\text { haritalama, çizim ve kolaj, maket yöntemleridir. }\end{array}$ \\
\hline
\end{tabular}


Etkinlik düzeyi değerlendirmesinde yöntemler sağladıkları kriterler arttıkça daha etkili olarak değerlendirilmektedir. Kriterlerin değerlendirmede farklı ağırlıkları olmasa da gerçek ve etkin katılımdan bahsedilebilmesi için karara etki kriterinde etkili olmaları oldukça önemlidir. Bu bağlamda Tablo 4'te uygulama örnekleri üzerinden yapılan değerlendirmede tüm uygulama örneklerinde çizim ve kolaj, odak grup tartışması yöntemlerinin kriterleri en çok sağlayan yöntemler olduğu görülmektedir. Kellyville Okul Bahçesi örneği dışında çalıştay/atölye yönteminin de kriterleri en çok sağlayan yöntem olduğu söylenebilir. Aynı zamanda bu üç yöntem tüm örneklerde karara etki eden yöntemler de olmuşlardır.

Çizim ve kolaj yöntemi çocukların kendilerini ifade etmelerini sağlamada en basit katılım yöntemidir. Birçok çocuk için bilinen, eğlenceli ve pahalı olmayan yöntemdir. 14 yaşın altındaki çocuklar için oldukça etkili bir yöntem olmaktadır. Çizim çalışmaları bireysel ya da ortak çalışma şeklinde yapılabildiğinden, bireysel ve grup katılımını da birlikte desteklemektedir. Kolaj çalışmasında da anlatım biçimlerinin karışık bir şekilde kullanılabilmesi (fotoğraflar, renkler, kelimeler ve çizimler) içerik olarak daha zengin bir anlatımın oluşmasını sağlamakta, çocuklar için de ilgi çeken alternatif araçlar sunmaktadır.

Odak grup tartışmaları belirlenen konuyla ilgili topluluğun geri kalanını temsil edebilecek özelliklere sahip seçilmiş kişilerden ve çocuklardan oluşan, bir kolaylaştırıcı eşliğinde yapılan grup çalışmalarıdır. Odak grup çalışmalarında gruplarda yer alacak çocuk sayısı uygulanacak proje ve elde edilmek istenen sonuca göre değișkenlik gösterebildiğinden, küçük gruplardan ya da geniş katılımlı gruplardan oluşabilir. Çocuklarla gerçekleştirilen odak grupların kolaylaştırıcıların desteği ile gerçekleștirilmesi, yöntemin etkinliğini de artırmaktadır. Yöntem için gerekli zamanının ve mekânın sağlanması yeterlidir, maliyeti düşük ve uygulaması basit bir yöntemdir.

Çalıştaylar/atölyeler ise tüm katılımcıları (çocukları, gençleri, yetişkinleri, kolaylaştırıcıları, paydaşları vb.) bir araya getirerek proje sürecinde mekânsal kararlar geliștirilmesini sağlayan oldukça etkili bir yöntemdir. $\mathrm{Bu}$ yöntemde çizimler, planlar, fotoğraflar, maketler gibi farklı görsel araçların kullanılabilmesi, çocuklar için farklı anlatım biçimlerinin kullanılmasını ve alternatifler geliştirilebilmesini sağlamaktadır. Bu yöntem de diğerleri gibi ortak çalışmaya olanak veren, yaş gruplarına göre kullanılan malzemeyle çeşitlendirilebilen, maliyeti düşük ve uygulaması basit yöntemlerdendir. Bu nedenle çizim ve kolaj, odak grup tartışması ve çalıştay/atölye yöntemleri tüm uygulama örnekleri için en etkin yöntemler olmuşlardır.

Tablo 4'te görüldüğü üzere katılım yöntemlerinin etkinliği, kullanıldığı uygulama örneklerine göre farklılıklar gösterebilmektedir. Bu nedenle tüm örnekler için kriterleri en az sağlayan ortak bir yöntemden bahsetmek mümkün değildir. Her bir projede etkin olmayan yöntemin birbirinden farklı olduğu görülmüştür.

Haritalama yöntemi, Freyberg Meydanı projesinde kriterleri en az sağlayan yöntemken, aynı zamanda karara doğrudan etki eden yöntemler arasında da yer almıștır. Bu durumda kriterlerin değerlendirmede farklı ağırlıkları olmasa da gerçek ve etkin katılımdan bahsedilebilmesi için yöntemlerin karara etki kriterini sağlamaları gerektiği dikkate alınmalıdır. Çocukların yaşları ve kültürlerine göre harita çizebilme yetenekleri farklılık göstermektedir. Bu nedenle haritalama yöntemi 5 yaş üzerindeki tüm çocuklar için genellikle uygun bir yöntem olduğundan Freyberg Meydanı projesinde karara etki eden bir yöntem olmuştur. Ancak her ne kadar 5 yaş üzerindeki çocuklar için genellikle uygun bir yöntem olsa da çocukların engel durumları, kültürleri, gelişen anlayış ve algıları doğrultusunda değişkenlik gösterebilmektedir. Haritalama yöntemi Freyberg Meydanı projesinde kriterleri en az sağlayan yöntem iken, Boulder Civic Area Park örneğinde ise kriterleri en çok sağlayan ve karara doğrudan etki eden yöntemlerden olmuştur. Bunun en önemli nedeni Boulder Civic Area Park projesi 
farklı yaş gruplarında çocukları içerdiği için projenin yaş gruplarına ve çocukların kültürlerine göre farklı katılım yöntemleri kullanması ile diğer örnek projelerden öne çıkmasıdır. Dokuz yaş ve üstü çocuklar gelişen kapasiteleri doğrultusunda hazır resimli sembol haritaları kullanabildiklerinden ve soyut sembolik haritalar oluşturabildiklerinden, Boulder Civic Area Park projesinde kullanılan pic-to play, photogrid gibi haritalama yöntemleri oldukça başarılı yöntemler olmuşlardır.

Oyunlaştırma ve maket yöntemleri; 4 yaş ve üstü olan çocuklar, oyuncaklar ve modeller kullanarak çevresini üç boyutlu modelleyebileceğinden ve bu nedenle küçük yaştaki çocuklar için uygun olduğundan ve Boulder Civic Area Parkı projesinde küçük yaşta olan çocuk grubu çoğunlukta olduğundan (8-9 yas 60 çocuk), proje için oldukça etkin yöntemler olmuşlardır. Yine bu yöntem aynı gerekçelerle Oyun Engel Tanımaz Parkı örneğinde de etkin bir yöntem olmuştur.

Alan gezisi yöntemi genellikle proje başlangıcında, karar ve tasarım süreçlerinden önce alanı tanımaya ve sorunlarını tespit etmeye yönelik gerçekleştirilen bir yöntem olmasına rağmen; Kellyville Okul Bahçesi projesinde tasarım ve karar süreçlerinin sonunda, uygulamaya/inşaata başlanmadan önce ve inşaat sürecinde kullanılan bir yöntem olduğundan, proje için etkin bir yöntem olmamıştır. Ancak Oyun Engel Tanımaz Parkı örneğinde alan gezisinin diğer projelerden farklı olarak etkin bir yöntem olmasının sebebi sadece projenin başlangıcında alanı tanımak ve algılamak için kullanılmaması, inşaat/uygulama süreci de dâhil olmak üzere projenin katılımcı süreci içerisinde tekrarlanan bir yöntem olmas1dır. Bu nedenle Oyun Engel Tanımaz Parkı projesinde alan gezisi yöntemi karara etki eden bir yöntem olmuştur. Kellyville Okul Bahçesi örneği dışında tüm uygulama örneklerinde kriterleri en çok sağlayan yöntem olan çalıştay/atölye yöntemi, birlikte çalışmayı ve uzun bir süreci gerektiren bir yöntem olduğundan küçük yaş grupları için çok uygun yöntemler değillerdir. Kellyville Okul Bahçesi örneği 6-7 yaşlarında küçük yaş grubundaki çocukları içerdiğinden çalıştay/atölye yöntemi bu örnekte etkin bir yöntem olamamıştır.

Medya ve iletişim yöntemi ise çocukların yaptıkları çalışmalar hakkında toplumun bilgi sahibi olması, çocukların kendi fikirlerini, görüşlerini beyan etmeleri, kendi bakış açılarını aktarmaları konusunda kullanılan bir yöntem olduğundan, Kellyville Okul Bahçesi projesinde aktif kullanılan bir yöntem olsa da karara ve tasarıma doğrudan etkisi bulunmadığ için kriterlerin çoğunu sağlayamamış ve etkin bir yöntem olamamıştır. Oyun Engel Tanımaz Parkı projesinde de proje sürecinde her ne kadar bu yöntemin aktif kullanılmasına ilişkin girişimlerde bulunulsa da (facebook hesabinin aktif kullanılacağının kararlaştırılması, ancak bunun uygulamaya geçirilememesi gibi) sadece çocukların sergide, parkın açılışında kullandığı bir yöntem olmasından dolayı etkin bir yöntem olamamıştır.

İnternet tabanlı katılım yöntemi ise anket yöntemi ile birlikte Fremantle Esplanade Gençlik Meydanı projesinde ön plana çıkmaktadır. İnternet tabanlı katılım yetişkin kontrolünde bir katılım süreci gerektirdiğinden, küçük yaştaki çocuklar için uygun bir yöntem değildir. Fremantle Esplanade Gençlik Meydanı projesinde 12-18 yaş arasinda 50 çocuğun ve 19-24 yaş arasında 53 gencin olmas1, anket ve internet tabanlı katılım yöntemlerini yaş grupları için uygun kılmış ve anket ve internet tabanlı katılım yöntemlerini proje için etkin bir yöntem olmasını sağlamıştır. Proje sürecinde, kullanılan yöntemlerin farklı aşamalarda farklı çıktılar elde etmek için tekrarlanarak kullanılmış olması, kullanılan yöntemlerin tamamını da etkin kılmıştır. Ancak Oyun Engel Tanımaz projesinde ise anket yöntemi, sadece diğer yöntemlerin kullanımı sonrasında yönteme ilişkin geribildirimleri toplamak için kullanıldığından, kararlara ve tasarıma etkili olmayarak kriterleri sağlamada yetersiz kalmış; proje için etkin bir yöntem olamamıştır.

Yöntemlerin etkinliğinde oldukça önemli bir başka husus da eğitim ile desteklenme kriterini sağlayıp sağlayamadığı ile ilgilidir. Kriterlerin değerlendirilmesinde 
tüm kriterler eşit ağırlıkta olsa da eğitim ile desteklenme kriterini sağlayan örneklerdeki kullanılan katılım yöntemlerinin daha etkin olduğu görülmüştür. Avonturis Doğa Oyun Alanı projesinde proje sürecinin çocuklara tasarım kararlarını almada ve tasarım senaryolarını oluşturmada destek sağlayabilecek bir eğitim programı ile eşgüdümlü olarak ilerletilmesi kullanılan yöntemlerin etkinliğini artırmıştır. Oyun Engel Tanımaz örneğinde de projedeki yöntemlerin kriterlerin çoğunu sağlıyor oluşu, proje sürecinin eğitim programı ile desteklenmesiyle doğrudan ilgili oldugu ve yöntemlerin karara etkili olmasını sağladığı düşünülmektedir. Uygulama örnekleri üzerinden yapılan etkinlik düzeyi değerlendirmesi bu iki örnek dışındaki uygulamalarda eğitim ile desteklenme kriterinin sağlanmadığı, dolayısıyla sürecin bir eğitim programı ile desteklenmediği görülmüştür. Eğitim programları da anlık bir uygulama olmadığından, programlı ve birbirini takip eden dinamik bir süreci gerektirdiğinden proje süreçlerinde tercih edilmediği düșünülmektedir.

Ayrıca yapılan etkinlik düzeyi değerlendirmesinde etkinliğin ölçülebilmesi bak1mından en önemli kriterler ise şeffaflık ve hesap verebilirlik kriterleridir. Projelerin katılımcı süreçlerinin raporlanarak geribildirim sağlanması ve bu raporların şeffaf bir şekilde paylaşılması etkinlik düzeyini etkilediği gibi etkinlik düzeyinin ölçülmesi açısından oldukça önemlidir. Etkinlik düzeyi değerlendirmesinin yapılabilmesi için sürecin raporlanarak geribildirimlerin sağlanması gerekmektedir. Bu çalışma kapsamında yapılan etkinlik düzeyi değerlendirmesinin öznel bir değerlendirme olması, uygulama örneklerindeki süreçlerin şeffaflığ 1 ve geribildirimleri sağlayacak geribildirim raporlarının yeterli düzeyde ve içerikte olmamasından kaynaklanmaktadır. Bu nedenle katılımcı süreçlerin raporlanması oldukça önemlidir.

Kullanılan yöntemler proje süreci içerisinde farklı aşamalarda farklı amaçlarda tekrarladığından, süreç içerisinde de farklı katılım düzeylerinde gerçekleşmişlerdir. Bu nedenle ele alınabilecek bir yöntem için tek katılım düzeyinde gerçekleştiğini söylemek mümkün olmadığı için, bu çalışmada yöntemler için katılım düzeyi açısından net bir değerlendirme yapılamamaktadır. Ancak yöntemlerin her biri süreç içerisinde farklı katılım düzeylerinde gerçekleşse de proje genelinde International Association for Public Participation (Uluslararast Halk Katılımı Derneği - IAP2)'nin tanımlamış olduğu; bilgilendirme, danışma, dâhil etme, işbirliği yapma ve yetkilendirme düzeyleri bakımından bir değerlendirme yapıldığında, katılımın genellikle işbirliği yapma düzeyinde gerçekleştiğini söylemek mümkündür. Uygulama örnekleri üzerinden sadece Oyun Engel Tanımaz Parkı projesinde kendin-yap atölyesi yetkilendirme düzeyinde gerçekleşmiş, diğer uygulama örneklerinde en fazla işbirliği yapma düzeyine ulaşan katılımcı bir süreç gerçekleştirilmiştir.

$\mathrm{Bu}$ kapsamda incelenen katılımcı süreçlerle gerçekleştirilmiş altı örnek projenin hepsinde katılımı sağlamaya yönelik birden fazla yöntemin kullanıldığı, katılımcı profiline (çocuk, genç, engel durumları, $y a s$ vb.) ve projenin amacina göre farklı yöntemlerin tercih edildiği görülmektedir. Farklı katılım yöntemlerinin kullanılmas1 farklı düzeylerde katılımı sağlarken, aynı yöntemin uygulamalardaki alternatif kullanımları ve çocukların yaş gruplarına göre katılım düzeyi ve etkinliğini değiştirebilmektedir. Katılım yöntemini ve etkinliğini değiştiren bir diğer husus da katılım sürecine dâhil olan aktörlerdir. Çocuk katılımı disiplinlerarası uzman bir yapıyı gerektirmektedir. Aynı zamanda katılımc1 süreçlerde doğrudan dâhil olması gereken disiplinlerarası uzman bir yapının öneminin yanısıra çocukların ebeveynlerinin de dolaylı olarak süreçlere etkisi bulunmaktadır. Çalışma kapsamında, kentsel tasarım projelerinin farklı katılım yöntemlerinin planlanması ve uygulanması sürecinde, yöntemlerin etkinlik düzeylerini artıracak bir kriterler dizininin ortaya konulabilmesi ve kullanılan farklı katılım yöntemlerine bağlı olarak projelerin de etkinlik düzeylerinin artabileceğinin ortaya konulabilmesi amaçlanmıştır. Örnek projelerin etkinlik düzeyi değerlendirmesinde, her bir proje 
kendi koşullarını ve öznelliklerini taşıdığı için kriterlerin değerlendirmesi açısından kesin yargılara ulaşabilmek oldukça zordur. Bu nedenle çalışma kapsamında yapılan etkinlik düzeyi değerlendirmesi bir deneme olup; bu bağlamda yöntemlerin farklı projelerde ya da bir projenin farklı aşamalarında kullanılış biçimi etkinlik düzeyi açısından farklılıklar getirdiğinden, her yöntemin etkili olduğu ve olamadığ1 yönlerinin belirlenmiş olması, proje süreçlerinde yöntemlerin geliştirilerek ve çeşitlendirilerek daha etkin hale getirilebilmesinde bir çerçeve sunmaktadır.

\section{Sonuç}

Çocukların planlama ve tasarım sürecine katılımına ilişkin ilk uygulamalar 1960'larda görülmeye başlamıştır. Değinildiği üzere, çocuk katılımı tanımı, ilk kez 1989'da BM Genel Kurulunca onaylanan Çocuk Haklarına Dair Sözleşme ile gündeme gelmiştir. Çocuk Haklarına Dair Sözleşme günümüzde de hala geçerliliğini koruyan ve bundan sonraki süreçlere referans olan en önemli gelişme olarak değerlendirilse de katılım maddelerinin Batılı bir eğilim göstermesi ve yaşanılan coğrafyaya göre değişkenlik gösteren kimlik gelişimi ve kültürü göz ardı etmesi gibi nedenlerle ülkemiz de dâhil olmak üzere birçok coğrafyada hala uygulanabilir değildir. Çocuklara ilişkin konferanslar, yayınlanan yasa ve mevzuat, düzenlenen antlaşmalar ve sözleşmeler, ÇHDS'yi takip eden 1990'lardan itibaren "çocuk ve katılım" kavramına giderek önem kazandırmıştır. Çocuk katılımı konusundaki yaklaşımların zaman içerisinde kolektif üretimi destekleyen "çocuklarla birlikte tasarlama yaklaşımına" doğru dönüştüğü görülmektedir. Bu süreçte de literatürde çocuklar için farklı katılım modelleri, düzeyleri ve yöntemleri tanımlanmaktadır.

Literatürde tanımlanan farklı katılım modellerinin ortak özelliği çocukların karar verme süreçlerine etkileri arttıkça katılım düzeyinde de yükselmenin gerçekleşeceğidir. Proje süreçlerine çocuğun ne ölçüde dâhil edilmesinin amaçlandığı, görüş ve önerilerinin karar verme sürecinde ne düzeyde etkili olduğu ve katılım sürecin- de güç-yetki dağılımının nasıl yapıldı̆̆ 1 katılım düzeylerinin belirlenmesinde etkili olmaktadır. Farklı düzeylerde katılım sağlama amaçlarının, katılım yöntemlerinde de çeşitliliğe neden olduğu; literatürde tanımlanmış olan farklı yöntemler olmakla birlikte, çocuk katılımında kullanılan yöntemlerin birçok etkene göre çeşitlendiği görülmektedir.

Katılım sürecinde uygulanacak tüm yöntemlerin uygun bir şekilde planlanması uygulamanın başarılı olmasını sağlayacaktır. Kullanılacak katılım yöntemlerinin belirlenmesi ve birbirleriyle olan ilişkilerinin düzenlenmesi başarılı bir katılım sürecinin en önemli aşaması olup, çocuklara ve yaşadıkları kültüre uygun yöntemler kullanılması, katılımın etkin olmasını sağlayacaktır.

Çocukların katılımı ile gerçekleştirilen uygulama örneklerinin araştırılmasında, katılımcı süreçle gerçekleşen uygulama örneklerinin yurtdışında yaygın olarak gerçekleştirildiği, ülkemizde ise çocuk katılımına verilen önemin yetersiz olması nedeniyle, katılımcı süreçle gerçekleştirilen uygulama örneklerinin az olduğu görülmüştür. Uluslararası ölçekte başarılı uygulama örnekleri bulunsa da ülkemizde yeterli uygulama örnekleri bulunmamakta ve yapılan çalışmalar da genellikle yapmacıklık/göstermelik (tokenizm) düzeyinde örnekler olmaktadır. Çalışma kapsamında katılım yöntemlerinin uygulanma biçimlerindeki farklılıkları ve süreç içerisinde katılım yöntemlerinin çeşitlendirilmesinin etkilerini ortaya koyabilmek amaciyla incelenen uygulama örneklerinin katılım süreçlerinde; alan gezisi, fotoğraflama, anket, odak grup tartışması, çalıştay/atölye, haritalama, çizim ve kolaj, maket, oyunlaştırma, internet tabanlı katılım, medya ve iletişim gibi farklı katılım yöntemleri kullanılmıştır. Uygulama örnekleri üzerinden yapılan değerlendirmede bu yöntemler arasından; odak grup tartışması, çalıştay/ atölye, çizim ve kolaj yöntemlerinin proje süreçlerinde en çok tercih edilen yöntemler olduğu; internet tabanlı katılım yönteminin ise en az tercih edilen yöntem olduğu görülmektedir. Odak grup tartışması, çalıştay/ 
atölye, çizim ve kolaj yöntemleri; kolay uygulanabilir, düşük maliyetli, farklı yaş ve engel gruplarına göre şekillendirilebilen, çocuklar için farklı anlatım biçimlerini kapsayan ve proje sürecinin her aşamasında uygulanabilen yöntemler olduğundan en çok tercih edilen yöntemlerdir. İnternet tabanlı katılım yönteminin ise her yaş ve engel grubu için uygun olmaması, yetişkin kontrolünde gerçekleştirilmesi gerektiği, uygulanması için uzun bir süreç gerektirmesi, kaynaklara erişim bakımından istenilen zamanda ulaşım kolaylığı sağlamaması gibi nedenlerle en az tercih edilen yöntem olduğu düşünülmektedir.

Açık kamusal mekân tasarımında belirlenen amaçlara ulaşmak için planlanan çocuk katılım süreçlerinde kullanılan yöntemlerin etkinliğinin belirlenmesi için etkinlik düzeylerini değerlendirmeye yönelik kriterler irdelenmiştir. Katılım yöntemlerinin etkinliği özellikle son yıllarda yoğun olarak tartışılan bir araștırma konusu olmakla birlikte, sürecin karmaşıklığı ve ölçülebilir verilerle değerlendirmeye elverişli olmaması kesin bir değerlendirme yönteminin geliștirilememesine neden olmaktadır. $\mathrm{Bu}$ nedenle değerlendirmenin nasıl yapılabileceğine dair netleşmiş yöntemlerin tanımlandığı da söylenememektedir. $\mathrm{Bu}$ çalışmada açık kamusal mekân tasarımı projelerinde kullanılan katılım yöntemlerinin etkinliğini değerlendirmeye yönelik bir çerçeve; literatürde tanımlanmış olan yöntemler ve değerlendirme kriterleri esas alınarak geliştirilmiş bir kriterler seti tanımlanmaya çalışılmıştır.

Tanımlanan kriter dizini ile örnek projeler üzerinden yapılan bu değerlendirmede, katılımı sağlamaya yönelik birden fazla yöntemin kullanıldığı, katılımcı profiline ve projenin amacına göre farklı yöntemlerin tercih edildiği, farklı katılım yöntemlerinin kullanılmasının farklı düzeylerde katılımı sağladığ uygulamalardaki alternatif kullanımlarının katılım düzeyini ve etkinliğini değiștirebildiği görülmüstür.

Kullanılan yöntemlerin hangi düzeyde katılımı sağladığı da yöntemin ve projenin etkinliği açısından oldukça önemlidir.
Kullanılan yöntemler proje süreci içerisinde farklı aşamalarda farklı amaçlarda tekrarladığından, süreç içerisinde de farklı katılım düzeylerinde gerçekleşmektedirler. Chawla'nın (2001) da belirttiği gibi hiçbir katılım düzeyi birbirinden bağımsız değildir ve birden çok katılım şekli aynı projede gözlemlenebilir. Bu nedenle ele alınabilecek bir yöntemin tek katılım düzeyinde gerçekleştiğini söylemek mümkün olmad1ğından, bu çalışmada yöntemler için katılım düzeyi açısından kesin yargılar içeren bir değerlendirme yapılmamıştır. Ancak proje genelinde International Association for Public Participation (Uluslararası Halk Katıllmı Derneği - IAP2)'nin tanımlamış olduğu; bilgilendirme, danışma, dâhil etme, işbirliği yapma ve yetkilendirme düzeyleri bakımından bir değerlendirme yapıldığında, katılımın genellikle ișbirliği yapma düzeyinde gerçekleştiği söylenebilmektedir. Ancak projeler genelinde katılımın işbirliği yapma düzeyinde gerçekleşmiş olması başarısız bir katılım sürecinin gerçekleştiğini göstermemektedir. Hart (1997) ve Francis ve Lorenzo (2006) "Çocuklarla birlikte tasarım" anlayışının benimsendiği uygulamalarda proaktif yaklaşımla çocuklarla birlikte üretmenin amaçlanmasını; çocukların, yetişkin tasarımcılarla ve plancılarla, program ve tasarım fikirleri geliştirmek için birlikte çalıştıkları müzakere şekli olarak bir tasarım biçimi olan proaktif sürecin gerçekleştirilmesini vurgulamaktadırlar. Literatürde müzakere şekli olarak tanımlanan proaktif sürecin ise IAP2'nin tanımlamış olduğu işbirliği yapma düzeyi ile eş değer olduğu söylenebilmektedir. Aynı zamanda Treseder (1997) de çocukların 'yeterince' yetkilendirilmesinin gerektiğini vurgulayarak, tam yetkinin çocuğa bırakıldığg çocuk liderliğinde katılımın değil de çocuklarla işbirliği yapılan müzakereci bir tutum sergileyen "çocuklarla birlikte tasarım"ın önemini ortaya koymaktadır. $\mathrm{Bu}$ nedenle örnek projelerde IAP2'de tanımlanan katılım düzeylerinde 'yetkilendirme' düzeyine ulaşılamamış olması, projelerin katılımcı süreçlerinin başarısız olduğu anlamına gelmemektedir. Aksine literatürde yetkilendirme düzeyinin her yaş grubundaki çocuklar için uygun görülmemesi ve 
müzakere şekli olarak tanımlanan proaktif sürecin gerçekleştirilmesinin öneminin vurgulanması, örnek projelerin işbirliği yapma düzeyinde gerçekleştirilmiş olmasını olumlu yönde desteklemektedir.

Etkin ve tam katılımın sağlanması, katılım sürecinde farklı yöntemlerin kullanılması, bu yöntemlerin birlikte değerlendirilmesi, katılımcı profiline (kültür, yaş, engel grubu, yetenek $v b$.), projenin amacina ve projeden elde edilmek istenen sonuca göre farklı yöntemler tercih edilmesi, bu yöntemlerin ihtiyaca göre proje süreci içerisinde farklı aşamalarda farklı amaçlarda tekrarlanması ve yöntemlerin etkinlik değerlendirme kriterlerini sağlaması ile mümkün olacağından; farklı katılım yöntemlerinin kullanılması farklı düzeylerde katılımı sağlayacak ve çocukların yaş gruplarına, kültürlerine ve değişen algılarına göre katılım düzeyini ve etkinliğini artıracaktır. Katılımın etkinlik düzeyini değiştiren bir diğer husus da katılım sürecine dâhil olan aktörlerdir. Bu nedenle aktörlerdeki disiplinlerarası uzman yapının işbirliği içerisinde bulunması ve uzman yapı ile birlikte çocukların katılım süreçlerinde dolaylı olarak etkisi olan ebeveynlerin de eğitim ile desteklenmesi gerekmektedir. Aktörler, çocukların gelişimsel özellikleri, doğal çevrelerindeki davranış akışları, vb. konularda bilgi sahibi olmaları ve çocukların deneyimlerini zenginleştirecek, davranışlarını destekleyecek ve duyularını geliştirecek mekânlar yaratmanın öneminin farkında olan kişiler olmalıdır. Bu nedenle çocuğa yönelik çalışmalarda psikolog/pedagog, tasarımc1/planc1, yetişkin işbirliğinin kurulması gereklidir. Çocuk katılım süreçlerinde doğrudan ya da dolaylı olarak sürece dâhil olan aktörlerin işbirliği, katılımın etkinliğini artırarak, etkin ve tam katılımı sağlayacaktır. Ayrıca etkin ve tam katılımının sağlanıp sağlamadığının, yani etkinlik düzeyinin ölçülebilmesi bakımından, yapılacak projelerin katılımcı süreçlerinin her aşamasının yeterli seviye ve içerikte raporlanarak paylaşılması gerekmektedir. Projelerin katılımcı süreçlerinin raporlanarak geribildirim sağlanması ve bu raporların şeffaf bir şekilde paylaşıııası ileride yapılacak proje süreçlerinin etkinliğinin ölçülebilmesinde kolaylık sağlayacaktır.
Sonuç olarak; açık kamusal mekân tasarımında belirlenen amaçlara ulaşmak için planlanan çocuk katılım süreçlerinde kullanılan yöntemlerin etkinliğinin belirlenmesi gelecekte daha etkili katılım süreçlerinin planlanmasında kolaylık sağlayacaktır. Örnek projelerin etkinlik düzeyi değerlendirmesinde, her bir proje kendi koşullarını ve öznelliklerini taşıdığı için kriterlerin değerlendirmesi açısından kesin yargılara ulaşabilmek oldukça zordur. Bu nedenle çalışma kapsamında yapılan etkinlik düzeyi değerlendirmesi bir deneme olup; bu bağlamda yöntemlerin farklı projelerde ya da bir projenin farklı aşamalarında kullanılış biçimi etkinlik düzeyi açısından farkl1lıklar getirdiğinden, her yöntemin etkili olduğu ve olamadığı yönlerinin belirlenmiş olması, proje süreçlerinde yöntemlerin geliştirilerek ve çeşitlendirilerek daha etkin hale getirilebilmesinde bir çerçeve sunmaktadır 


\section{Kaynakça}

Arnstein, S.R. (1969). A Ladder of citizen participation. Journal of The American Institute Planners, 35 (4), s.216-224, United States. doi: $10.1080 / 01944366908977225$

Bang The Table. (2017). International public participation models 1969 - 2016. Erisim adresi: http://www. bangthetable.com/international-public-participation-models-1969-2016

Chawla, L. (2001). Evaluating children's participation: Seeking areas of consensus. PLA Notes, 42 , s.9-13. Erişim adresi: https://pubs.iied.org/pdfs G01959.pdf

Crowley, A ve Skeels. A. (2010). Getting the measure of children and young people's participation: An exploration of practice in Wales. A Handbook of Children and Young People's Participation: Perspectives from Theory and Practice, (ed. Barry Percy-Smith ve Nigel Thomas), s.184-192, New York. doi: 10.4324/9780203871072

Çocuk katılımının yolları: Başlangıçlar-fırsatlar-yükümlülükler. (t.y.). Erişim adresi: http://www. baskabirokulmumkun.net/cocuk-katilimin-yollari-baslangiclar-firsatlar-yukumlulukler/

Davies, T. (2009). Can social networks bridge the participation gap?. Erişim adresi: http:// www.timdavies.org.uk/2009/05/18/ can-social-networks-bridge-the-participation-gap/

Davies, T., Bhullar, S. ve Dowty, T. (2011). Rethinking responses to children and young people's online lives. EU Kids Online 2 Final Conference. id: 273226. Erişim Adresi: https://eprints.soton. ac.uk/273226/

Driskell, D. (2002). Creating Better Cities with Children and Youth: A Manual for Participation. Unesco Publishing \& Earthscan Publishing, Londra.

Fletcher, A. (2003): Purpose, empowerment and the experience of volunteerism in community. Freechild Project. Erișim Adresi: https://adamfletcher. net/purpose-empowerment-and-the-experience-of-volunteerism-in-community/

Francis, M. ve Lorenzo, R. (2002). Seven realms of children's participation. Journal of Environmental Psychology, 22, s. 157-169. doi: 10.1006/ jevp.2001.0248

Francis, M. ve Lorenzo, R. (2006). Children and city design: Proactive process and the "renewal" of childhood. Spencer, C., Blades, M. (eds.), Children and Their Environments: Learning, Using and Designing Spaces, s. 217-237. Londra: Cambridge University Press. doi: 10.1017/ CBO9780511521232.014

Hart, R. A. (1992). Children's participation, from tokenism to citizenship. (1. Bask1) New York: UNICEF. ISBN: 88-85401-05-8

Hart, R. A. (1995). The right to play and children's participation. The Article 31 Action Pack: Children's Rights and Children's Play, Shier $\mathrm{H}$. ed. Play-Train: Birmingham.

Hart, R. A. (1997). Children's Participation: The Theory and Practise of Involving Young Citizens in Community Development and Environmental Care. London: Earthscan Publishing.

International Association for Public Participation (IAP2). (2007). Spectrum of public participation. Erişim adresi: http://iap2canada.ca/page-1020549

Lardner, C. (2001). Youth participation - a new model. Edinburgh: Youth Social Inclusion Partnership.
Participation Models. (2012). Participation models: Citizen, youth, online. A chase through the maze. Models of Participation \& Empowerment. 2. Bask1. Erişim Adresi: https://www.nonformality.org/ wp-content/uploads/2011/07/ParticipationModels-20110703.pdf

Rowe, G. ve Frewer J. L. (2000). Public participation methods: A framework for evaluation. Science, Technology and Human Values, 25:3. doi: 10.1177/016224390002500101

Save The Children (2005). Practice standards in children's participation. Erişim Adresi: https:// resourcecentre.savethechildren.net/library/ practice-standards-childrens-participation

Shier, H. (2001). Pathways to participation: openings, opportunities and obligations. Children and Society,15, s. 107-117. doi: 10.1002/CHI.617

Shier, H. (2010). Pathways to participation revisited: Learning from Nicaragua's child cofee-workers. A Handbook of Children and Young People's Participation: Perspectives from Theory and Practice, (ed. Barry Percy-Smith ve Nigel Thomas), s.215-229, New York.

Shier, H. (2014). A change of rhythm, Nicaraguan style, in children and young people's participation. Save The Children. ISBN: 979-99955-72-68-9. Erişim Adresi: http://www.harryshier.net/docs/ShierChange_of_Rhythm.pdf

Şentürk, G. (2018). Açık Kamusal Mekân Tasarımında Çocuk Katılım Yöntemlerinin Etkinlik Düzeyi Değerlendirmesi (Yüksek Lisans Tezi). Mimar Sinan Güzel Sanatlar Üniversitesi, Fen Bilimleri Enstitüsü, İstanbul.

Treseder, P. (1997). Empowering children and young people: promoting involvement in decision-making. Save The Children.

UNCRC (2009). Birleşmiş Milletler Çocuk Haklarına Dair Sözleșme, Çocuk Hakları Komitesi, Elli birinci oturum, Cenevre, Genel Yorum No.12(2009) Çocuğun Katılım Hakkı, CRC/C/GC/12.

UNCRC (2014). Working methods for the participation of children in the reporting process of the Committee on the Rights of the Child. Convention on the Right of the Child. $\mathrm{CRC} / \mathrm{C} / 66 / 2$ (141856). Erişim Adresi: https://resourcecentre.savethechildren.net/node/15415/pdf/g1418656.pdf

UNICEF (2001). The participation rights of adolescents: $a$ strategic approach. New York: UNICEF.

Wong, N.T., Zimmerman, M.A. ve Parker, E.A. (2010). A Typology of Youth Participation and Empowerment for Child and Adolescent Health Promotion. American Journal of Community Psychology, 46, 100-114. doi: 10.1007/ s10464-010-9330-0 